\title{
Review of Bionanocomposite Coating Films and Their Applications
}

\author{
Mhd Abd Cader Mhd Haniffa ${ }^{1,2}$, Yern Chee Ching ${ }^{1, *}$, Luqman Chuah Abdullah ${ }^{3,4}$, \\ Sin Chew Poh ${ }^{1}$ and Cheng Hock Chuah ${ }^{2}$ \\ 1 Department of Mechanical Engineering, Faculty of Engineering, University of Malaya, \\ Kuala Lumpur 50603, Malaysia; mmmhaniff@yahoo.com.sg (M.A.C.M.H.); pohsc@um.edu.my (S.C.P.) \\ 2 Department of Chemistry, Faculty of Science, University of Malaya, Kuala Lumpur 50603, Malaysia; \\ chchuah@um.edu.my \\ 3 Department of Chemical Engineering, Faculty of Engineering, University Putra Malaysia, \\ Serdang 43400, Malaysia; chuah@upm.edu.my \\ 4 Institute of Tropical Forestry and Forest Product (INTROP), University Putra Malaysia, \\ Serdang 43400, Malaysia \\ * Correspondence: chingyc@um.edu.my; Tel.: +60-3-7967-4445; Fax: +60-3-7967-5317
}

Academic Editor: Naozumi Teramoto

Received: 2 February 2016; Accepted: 13 June 2016; Published: 29 June 2016

\begin{abstract}
The properties of a composite material depend on its constituent materials such as natural biopolymers or synthetic biodegradable polymers and inorganic or organic nanomaterials or nano-scale minerals. The significance of bio-based and synthetic polymers and their drawbacks on coating film application is currently being discussed in research papers and articles. Properties and applications vary for each novel synthetic bio-based material, and a number of such materials have been fabricated in recent years. This review provides an in-depth discussion on the properties and applications of biopolymer-based nanocomposite coating films. Recent works and articles are cited in this paper. These citations are ubiquitous in the development of novel bionanocomposites and their applications.
\end{abstract}

Keywords: bionanocomposite; coating film; crosslink; nanomaterials; biodegradable polymers

\section{Introduction}

Bionanocomposite coating films are composite materials that consist of natural or synthetic biodegradable polymers and nano-scale materials. Bionanocomposites are known as a novel class of advanced materials. In these materials, the polymer matrix, which includes natural or synthetic polymers or biomolecules, is considered the biological origin, whereas nano-scale materials are regarded as value-added materials. Composite materials exhibit stronger physical, chemical and mechanical properties than their constituent materials. However, conventional composite materials mechanically differ from nanocomposites because of their exceptionally high surface-to-volume ratio. Nanocomposites are incorporated with a large variety of systems, including organic and/or inorganic materials as the general class and either one of the phases with one, two, or three dimensions less than $100 \mathrm{~nm}$. In recent years, researchers and industries have been moving toward developing bio-based nanocomposites to address environmental issues and to find alternative sources for petroleum-based chemicals. The results of recent studies show that bionanocomposites are excellent green technology materials with good biodegradability, biocompatible properties, and the capability to mimic bio materials. Consequently, bionanocomposites have been ubiquitous in numerous applications, including coating films, which have been realized via novel and conventional research and technologies. 
Natural or synthetic biodegradable polymers play a major role in the fabrication of bionanocomposite coating films incorporated with nano-scale materials. The properties and applications of a bionanocomposite coating film depends on the characteristic of the nano-scale materials. Several natural polymers have been categorized in previous studies, and each of these materials inherently possesses different characteristics, such as molecular arrangement, active functional groups, bonding nature, thermal behavior, and solubility. Apart from inorganic or synthetic organic compounds, some minerals and clay minerals are also used as nano-scale materials to fabricate bionanocomposite coating films. These materials are utilized in various interdisciplinary fields such as bio-inspired materials, bio-mineralization processes, and biomimetic systems [1]. Furthermore, the properties of a bionanocomposite coating films depend on the characteristics of the biopolymers, the stoichiometric ratio of the constituent materials, and the cross-linking among the constituent materials as well as on the biopolymer macromolecular matrix. The applications of bionanocomposite coating films have been ubiquitous in different industries, such as aerospace, food, biomedical, tissue engineering, paint, packaging, and glass coating.

This paper aims to review studies on polymer-based nanocomposite coating films and their applications. Furthermore, the UV-blocking properties of biopolymers and recently fabricated bionanocomposite coating films are comprehensively discussed. Film characterizations are presented as well.

\section{Constituent Materials of Bionanocomposite Coating Films}

Natural polymers are found in renewable resources such as cellulose, wood fiber, starch, chitosan, pullulan, alginate, protein, shellac, lignin, and polyhydroxyalkanotes. They are used in many industrial and biomedical applications such as in preparing implant devices, biomimetic materials, films, coating materials [2], insulation materials, paints, paint inks, biodegradable packing materials, adhesives, footwear components, synthetic leathers, lubricants, biodiesel, and plasticizers [3]. In addition, main class synthetic biodegradable polymers, including polyglycolide, polylactic acid, polybutylene succinate and poly(vinyl alcohol) (PVOH) and other biodegradable polyurethanes, are reviewed in this paper. Types of nanoscale materials, their significance and loading level into a polymer matrix as well as an effect of nanoscale materials on coating application are discussed. Moreover, a range of applications and properties of film-forming materials are investigated in this review.

\subsection{Natural Polymers}

Six natural polymers, such as plant cellulose, lignin, chitosan, pullulan, polyhydroxyalkanoate, and protein are discussed in this review based on their source of origin, chemical structure, functional group, potential surface modifications, and their applications.

\subsubsection{Cellulose}

Cellulose is one of the major natural and renewable biopolymer resources. It is extensively used in fabricating advanced polymer-based nanocomposite materials in the form of cellulose nanocrystals (CNCs), and is adopted in the sustainable production of materials on an industrial scale [4]. Cellulose exists as a cellular hierarchical biocomposite in all wood and plant materials incorporated in other materials such as lignin, hemicelluloses, waxes, extracts and trace elements [5]. A graphical illustration of cellulose is provided in Figure 1. The molecular arrangement and bonding nature of cellulose in plant cell wall have been clearly presented by Habibi et al. [6]. CNCs are well-ordered crystalline structures within cellulose fibers which is composed of amorphous and crystalline regions. CNCs are formed by the breakup of microfibrils into shorter crystalline parts. CNCs have been mainly referred to as microcrystals, whiskers, microcrystalline, nanofibers, or nanofibrils in recent years. Different mechanical and chemical treatments have been used to prepare CNCs. Further individualization of CNCs occur by using cryocrushing, disintegration and defibrillation processes [7]. 


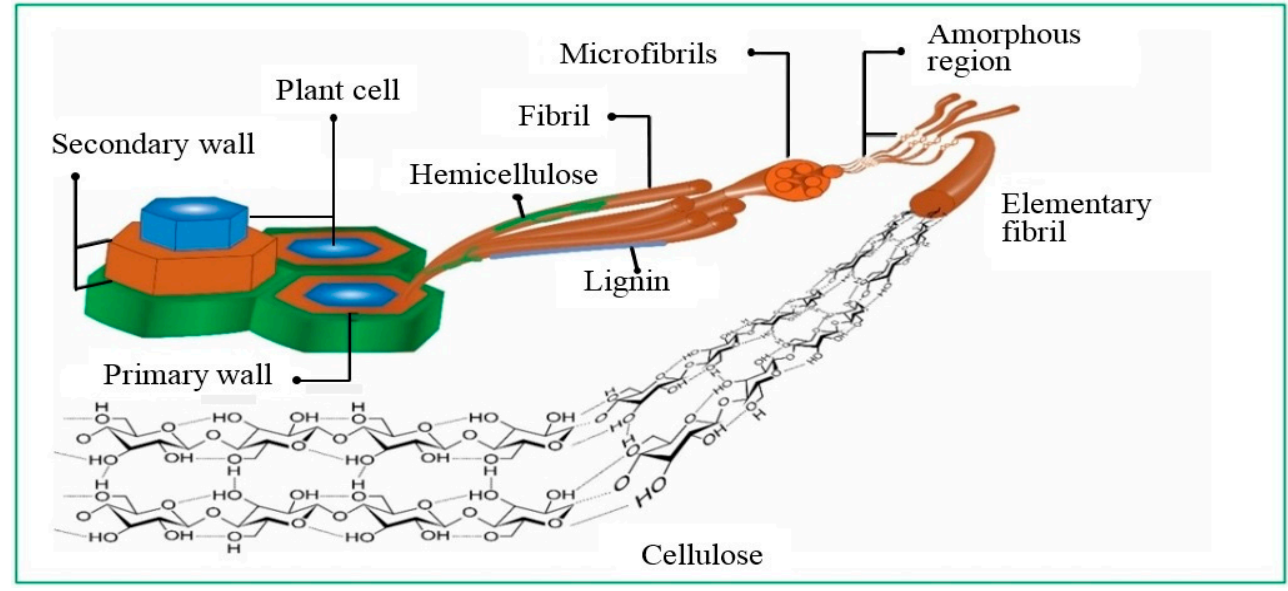

Figure 1. Graphical illustration of the hierarchical structure of cellulose extracted from plants.

Considering the hydrogen bond in their crystalline region, CNCs exhibit good strength and insoluble nature in most solvents. The mechanical properties such as the theoretical values of Young's modulus, tensile strength, and elongation at break modulus of the CNCs of cotton and tunicate were reviewed by Habibi et al. [6]. The mechanical properties of some plant fibers are listed with their values in Table 1.

Table 1. The mechanical properties of plant fibers with an increasing order of tensile strength [8].

\begin{tabular}{ccccc}
\hline Fibers & Density & $\begin{array}{c}\text { Elongations at break } \\
(\mathbf{\%})\end{array}$ & $\begin{array}{c}\text { Young's modulus } \\
\text { (GPa) }\end{array}$ & $\begin{array}{c}\text { Tensile strength } \\
\text { (GPa) }\end{array}$ \\
\hline Coconut & 1.15 & $15-40$ & $4-6$ & $131-175$ \\
Bamboo & $0.6-1.1$ & - & $11-17$ & $140-230$ \\
Kenaf & 1.2 & 1.6 & $14-53$ & $240-930$ \\
Cotton & $1.5-1.6$ & $7-8$ & $5.5-12.6$ & $287-597$ \\
Flax & 1.54 & $1-4$ & $27.5-85$ & $345-2000$ \\
Sisal & $1.45-1.5$ & $2-7$ & $9-22$ & $350-700$ \\
Hemp & 1.47 & 1.6 & $17-70$ & $386-800$ \\
Jute & 1.44 & $1.5-1.8$ & $10-30$ & $393-773$ \\
Ramie & $1.5-1.56$ & $1.2-3.8$ & $27-128$ & $400-1000$ \\
Nettle & 1.51 & $2.1-2.5$ & $24.5-87$ & $560-1600$ \\
E-glass & 2.5 & 2.5 & 70 & $2000-3500$ \\
Carbone & 1.4 & $1.4-1.8$ & $230-240$ & 4000 \\
\hline
\end{tabular}

The cell wall is composed of several complex layered structures with primary and secondary walls. The primary wall has three layers which are covered by the secondary wall. Each layer is composed of microfibrils, and the thick middle layer of the secondary wall determines the mechanical properties of the fibers. The presence of fiber with an optimum quantity determines the mechanical strength of advanced polymer-based nanocomposites. Therefore, understanding the physical, chemical and mechanical properties of natural fiber is a value-added concept to develop improved natural polymer-based nanocomposites. The properties of the natural fibers are not only dependent on weather condition, soil, and climate, but are also affected during the processing of the fiber, such as during retting, scotching, bleaching, and spinning [9].

Cellulose fibers are used as reinforcing materials in several industries because of their high thermal stability, high aspect ratio, relatively high strength, low density, excellent tensile strength, high durability, good mold capability, and high stiffness [10]. Furthermore, these fibers are abundantly available, biodegradable, biocompatible, cheap, renewable, have low abrasive nature, and exhibit good mechanical properties. In addition to these inherent properties, surface modification treatments 
also enhance the characteristics of CNCs. Such treatments are possible because of the abundance of the hydroxyl group on CNC surface. The results showed that various chemical processes such as silylation [11], esterification, etherification, oxidation, and polymer grafting [6] have successfully functionalized CNCs in recent years.

The archetypal properties and chemical modification possibilities of CNCs have directed the considerable academic and industrial interests toward the potential of these materials in various applications, such as in coating films [12], nanopaper (Figure 2), nanocomposites [13], high-performance materials, biomedicals, catalysts, sensors, electronics, and energy [14,15]. However, CNCs have poor water-vapor barrier capacity because of the huge amount of hydroxyl groups on the nanofibrillated cellulose surface.

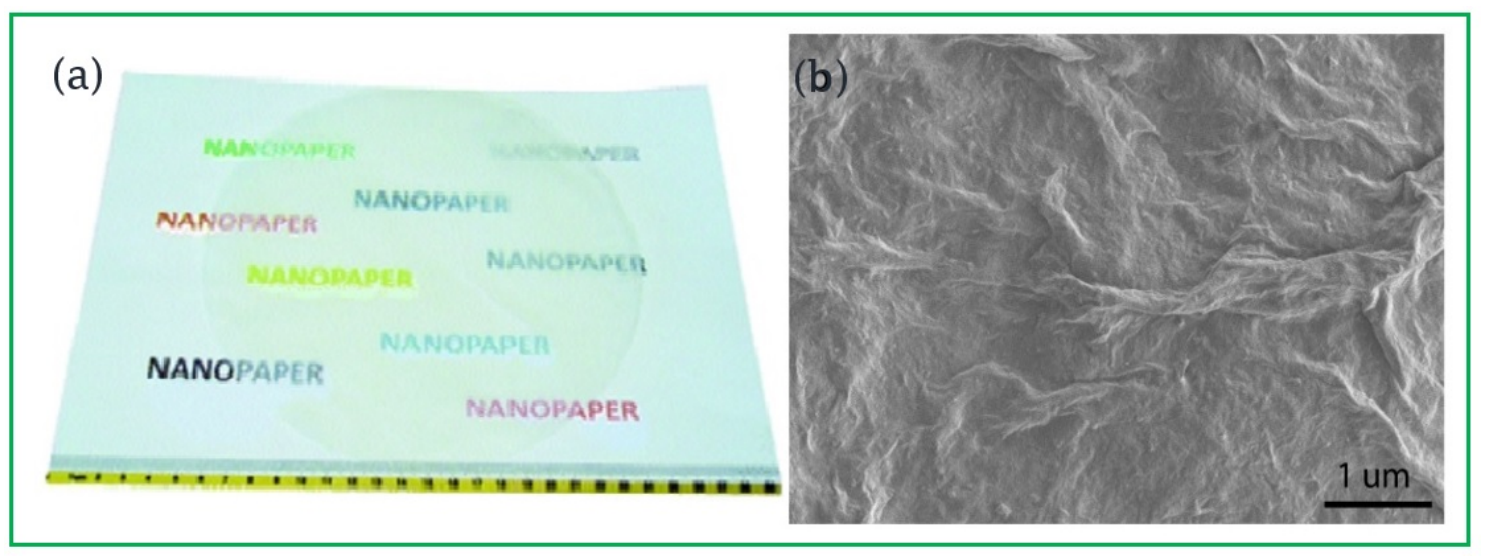

Figure 2. (a) Photograph of a $200 \mathrm{~mm}$ diameter cellulose nanopaper structure on top of conventional A4 copy paper; (b) Scanning electron micrograph of hybrid microfibrillated cellulose nanofibers/montmorillonite nanopaper surface. Reprinted (adapted) with permission from [16], copyright (2016) American Chemical Society.

\subsubsection{Chitosan}

Chitosan is an extraordinarily versatile natural polymer. It is known as one of the most promising biopolymers for fabricating advanced materials $[17,18]$. Next to cellulose, chitosan is the second most abundant polysaccharide found in nature $[19,20]$. Furthermore, over 100 billion tons of chitosan have been converted annually from living materials through the deacetylation process of chitin. Chitosan is a polyamino-saccharide that consists of active primary amine, primary hydroxyl, and secondary hydroxyl groups on its molecular chain known as $\beta$-(1-4)-2-amino-2-deoxy-D-glucose. These unbranched molecular units act as functional monomers, which form the chitosan polymer.

The active primary amine and hydroxyl groups of chitosan allow its structural modification with suitable cross-linking agents. Accordingly, the physical properties of chitosan are enhanced, whereas swelling degree in its aqueous system is reduced [18]. Cross-linking agents for chitosan, such as glyoxal, glutaraldehyde, epichlorohydrin, genipin, ethylene glycol diglycidyl ether, $N, N^{\prime}$-methylenebisacrylamide, and sulfuric acid, have been intensively reviewed by $\mathrm{Xu}$ et al. [18]. They also investigated the cross-linking mechanism, preparation methods, toxicity, hydrophobicity, feasibility, and drawbacks of these agents. Chitosan has been extensively used in several fields, such as in medicine, protein separation and identification, chiral compound separation, and coating field as well as the winemaking industry because of its physical robustness, thermal stability [18], bivalent mineral-chelating capability and antibacterial behavior [21]. However, chitosan has poor mechanical properties, water resistance limit, and gas-barrier capability. Therefore, its application is only possible in the presence of water and humidity [22,23]. Cationic polysaccharide of chitosan are highly sensitive, and thus, heterogeneous materials that exhibit inadequate properties with trace amounts of anionic substances and nanoparticles in the solution are formed [24]. However, countless 
strategies, such as the addition of plasticizers and salt, the chemical modification of hydroxyl groups, the cross-linking of polysaccharides, the use of suitable solvents, the change of $\mathrm{pH}$, the addition of different polysaccharides, and the blending with other polymers, have been studied to improve the mechanical properties and other properties of chitosan $[17,25]$.

Chitosan is a positively charged polysaccharide used in medical and drug delivery applications [26,27]. Interestingly, a recent novel approach on electrostatic interaction, in which cationic polysaccharides are combined with anionic substances and nanoparticles, has turned the drawback of cationic polysaccharides in an aqueous medium into an advantage to develop bionanocomposites using chitosan as a building block. The results of an ionic system of chitosan can act as a weak polyelectrolyte to generate a charged and non-charged state. The charging of the system can also be manipulated by directly changing the $\mathrm{pH}$ value [28].

\subsubsection{Lignin}

Lignin is the second-most abundant natural renewable biopolymer derived from plant materials. In addition, over 70 million tons of lignin is derived annually for different purposes. In 2002, 95\% of lignin was used in the form of energy [28] and only $1 \%-2 \%$ was used in industrial products [29]. Lignin exhibits variability in terms of building units and functional groups, including ether and ester linkages, aliphatic and aromatic hydroxyl groups, and methyl groups [30]. Furthermore, aromaticity and bonding nature of the lignin with polysaccharides in the plant cell wall have been discussed by Hambardzumyan et al. [31]. Figure 3 describes the molecular organization, functional groups, and length of a molecular unit.

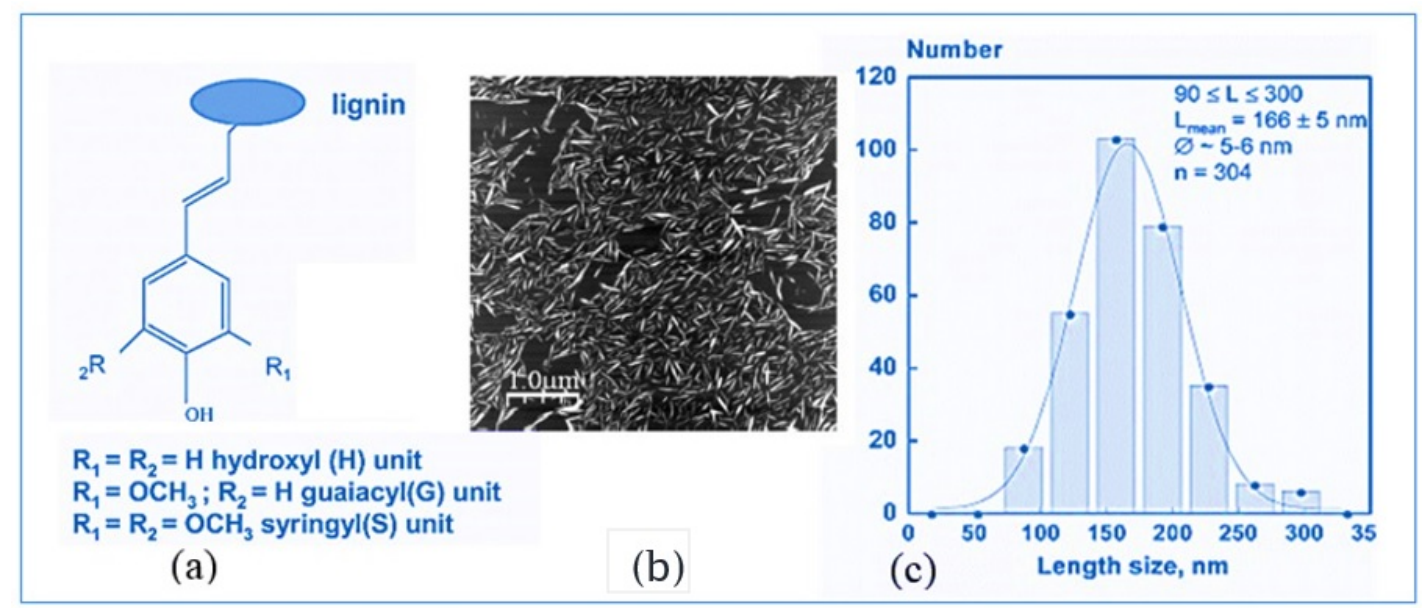

Figure 3. (a) The chemical structure of the monomer units found in lignin; (b) AFM image of cellulose nanocrystals after acid hydrolysis and (c) the average length of the monomer unit found in lignin. Reprinted (adapted) with permission from [31], copyright (2016) American Chemical Society.

Lignin is not only enhanced by its aromatic nature and functional groups, but also by its considerable potential adhesive, stabilizing, and suspension-forming properties to present a highly reactive nature. Consequently, lignin is regarded as a good additive for developing biodegradable composite materials and also as a stabilizing agent for ceramics and as an effective alumina suspension for advanced material fabrication. In addition, lignin inherently possesses UV-absorbing capability [32] and demonstrates good mechanical resistance, recalcitrance to biodegradation, and hydrophobic properties.

Meanwhile, recently developed chemically modified lignin, such as lignosulfates, kraft lignin, and acetylated lignin, which contain CNCs or commercial derivatives or nanocellulosic polysaccharides, further improved the hydrophobicity, mechanical resistance, and oxygen barrier properties of the materials. Furthermore, a lignin-based nanocomposite incorporated with CNCs improves the surface 
water resistance and wettability properties of the materials in the presence of Fenton's reagent $\left(\mathrm{H}_{2} \mathrm{O}_{2}\right.$ and $\mathrm{FeSO}_{4}$ ) as an initiator. Graft copolymerization is a simple and attractive approach to change the physical and chemical properties of lignin [32]. Several techniques have been used to modify lignin through the graft copolymerization processes, such as irradiation, chemical, and chemo-enzymatic initiation [33]. The limitation of the biodegradability of lignin copolymer incorporated with vinyl monomers is a drawback in most free radical-based graft copolymerization techniques [34].

Consequently, poly-( $\varepsilon$-caprolactone) and L-lactide [35,36] have been invented as alternative monomers to fabricate biodegradable materials from copolymerized lignin. The ring-opening polymerization technique is extensively used to prepare lignin-graft polylactic acid (PLA) and polycaprolactone (PCL) copolymers [37] with a suitable catalyst. The thermal stability and soluble characteristics of lignin and lignin-based copolymers were reported by Kim et al. [32] and illustrated in Figure 4.

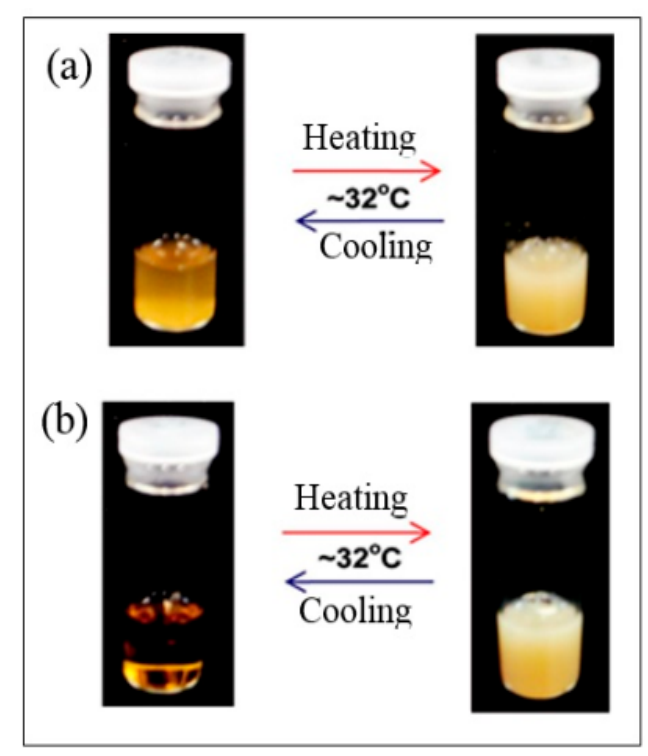

Figure 4. Visual appearance of the phase transition of (a) lignin- $g$-poly( $N$-isopropylacrylamide) copolymer and (b) lignin- $g$-poly $(N$-isopropylacrylamide) copolymer fully substituted macroinitiator. Reprinted (adapted) with permission from [32], copyright (2016) American Chemical Society.

\subsubsection{Pullulan}

Pullulan is another type of natural polymer produced by particular strains of the polymorphic fungus, Aureobasidium pullulans as an extracellular, water-soluble polysaccharide. Aureobasidium pullulans is a ubiquitous fungus found in environmental samples such as soil and water, particularly as an early-colonizing saprophyte on decaying leaf litter, wood, and many other plant materials, in which they utilize cellobiose but not cellulose [38]. Pullulan is a commercially emerging biopolymer used in diverse industrial applications such as pharmaceutical, chemical, energy production, agriculture, and food industries, among others. It is a linear homopoly-saccharide consisting of regularly repeating maltotriose (or trimer) subunits connected via $\alpha-(1 \rightarrow 6)$ glycoside linkage. Maltotriose is a polysaccharide with $\alpha-(1 \rightarrow 6)$ linkage with $(1 \rightarrow 4)-\alpha$-D-triglucosides, illustrated in Figure 5 . Furthermore, out of the total residue, only $1 \%-7 \%$ of maltotetraose (tetramer) subunits can also be possible in pullulan [39]. 


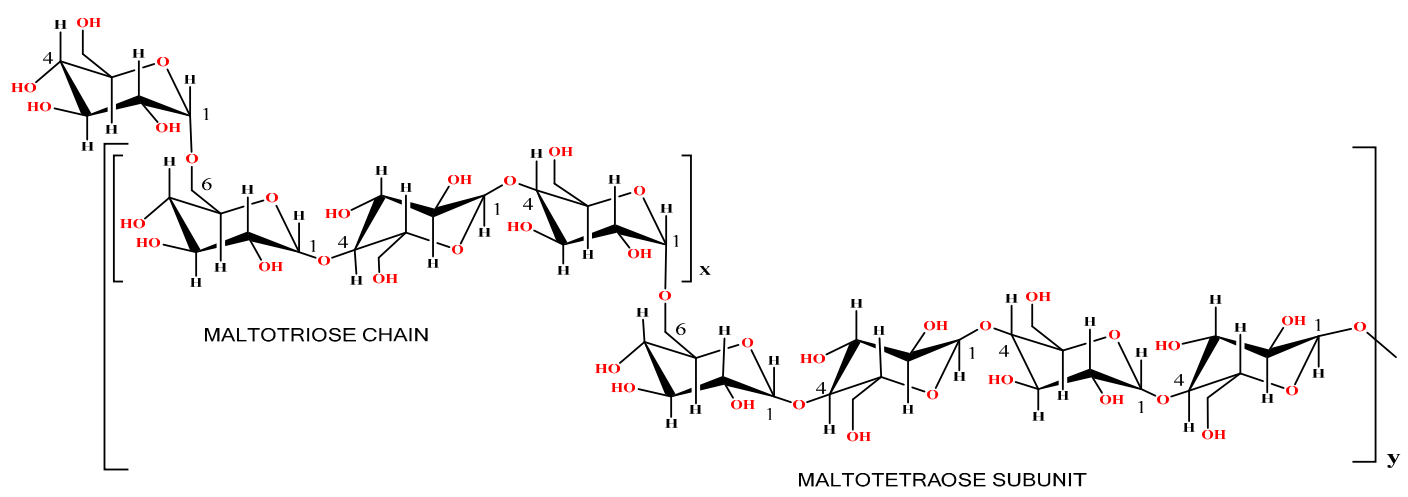

Figure 5. Molecular structure of pullulan with maltotriose and maltotetraose subunit.

The unique pattern of the $\alpha-(1 \rightarrow 6)$ linkages among the maltotriose subunits provides distinctive physical properties of pullulan including high water solubility and structural flexibility $[39,40]$. Consequently, these properties endow the pullulan with physical traits, along with adhesive properties, and enable its capacity for compression, thereby molding strong, oxygen-impermeable films and forming fibers. Leather [41] reported that pullulan fibers and films similar to certain synthetic polymers (plastic derivatives from petroleum) possess oxygen impermeability compared with other polysaccharide films.

Pullulan is highly water soluble, insoluble in organic solvents, non-hydroscopic, and possesses relatively different viscosity than other polysaccharides, i.e., relatively low as compared to most gums, particularly the Arabian gum. Arabian gum has an extremely lower viscosity of $\sim 80-120 \mathrm{cP}$ : with that same concentration, the viscosity of pullulan solution is $\sim 22,000 \mathrm{cP}$. However, pullulan is significantly less viscous than other gums [42].

Yeast, similar to the form of strain Aureobasidium pullulans QM 3090, is the primary producer of pullulan and the production is controlled by the culture medium ( $\mathrm{pH}$ value) as well as the temperature (optimal temperature ranging from 24 to $32^{\circ} \mathrm{C}$ ) [43]. Several substrates exist, such as sucrose, glucose, fructose, maltose, starch, or oligosaccharides and others can be used as a substrate for pullulan production. Among them, sucrose is frequently used for this purpose [44].

Several studies have reported on surface modification of pullulan, with the main focus on etherification [45], hydrogenation [46], carboxylation [47], esterification [48], chloroformate activation and succinoylation [49]. Shibata et al. [50] reported a peaceful surface modification of pullulan via phenyl isocyanate (PIC) and hexyl isocyanate (HIC) with clear glass transition temperature $\left(T_{\mathrm{g}}\right)$. Hasuda et al. [51] synthesized photo-reactive pullulan using the photo-immobilization technique, and they concluded that photo-reactive pullulan is covalently immobilized on various surfaces; furthermore, pullulan significantly reduces the interaction with protein and cells. Hydrophobically modified pullulan was synthesized by Kuroda et al. [52] using a cholesteryl-bearing pullulan (CHP) and hexadecyl group-bearing pullulan (C16P) via hierarchical self-assembly techniques. Viscosity of the semi-dilute solution (approximately above $2 \mathrm{wt} \%$ ) of CHP and C16P drastically increased but they formed macroscopic gels at a high concentration [52]. Another study used 3-amminopropyltrimethoxysilane to modify the surface of pullulan via graft-polymerization technology [53].

Pullulan polymer-based nanomaterial and nanocomposite materials have been fabricated in recent years, and they are applied in highly specific fields. In particular, adriamycin-loaded pullulan acetate (PA) and sulfonamide conjugate nanoparticles, as well as PA and oligo-sulfadimethoxine conjugate self-assembled $\mathrm{pH}$-sensitive hydrogel nanoparticles, are used for treating breast tumor cell line (MCF-7), tumor, ischemia and inflammation [54].

Alternatively, pullulan-based bionanocomposite coating materials have been fabricated the first time, incorporated with montmorillonite via the ultrasound-assisted procedure for the exfoliation of inorganic tactoids. Consequently, the coating material exhibits a high oxygen barrier [55].

The pullulan-based sustainable nanocomposite films were characterized by Trovatti et al. [56], with the incorporation of bacterial cellulose. Nonetheless, thermal and mechanical properties of the 
composite films were enhanced by the nanofibrillated cellulose. Pinto et al. [57] fabricated a transparent nanocomposite thin film based on pullulan polymer incorporated with silver nanoparticles. In addition, pullulan and 6-carboxy pullulan-mediated silver nanoparticles were fabricated by Coseri et al. [58].

\subsubsection{Polyhydroxyalkanoate (PHA)}

Polyhydroxyalkanoate (PHA) is a linear bio-polymer synthesized by microorganisms including many Gram-positive and Gram-negative bacteria under unbalanced growth conditions for energy storage [59]. Several countries participate in fabricating the PHA worldwide; among them are the USA and China, leading by nearly 50,000 and 10,000 tons per year, respectively. PHA closely resembles the synthetic thermoplastic and most promising biopolymer, possessing complete biodegradability and biocompatibility [60]. Accordingly, PHA is attractive to various applications, such as tissue engineering, packaging, drug delivery, and medical bio-implants.

Molecular arrangement of PHA is categorized into two major types of PHA, namely, short-chain length (SCL-PHA) and medium-chain length (MCL-PHA) hydroxyalkonoic acid. These two types are distinguished based on the carbon chain length. Poly (3-hydroxybutyrate) (PHB), poly (3-hydroxyvalerate) (PHV), and their copolymer poly (3-hydroxybutyrate-C-hydroxyvalerate) (PHBV) are in the first category, whereas the second category includes the poly (3-hydroxyoctanoate) (PHO) and poly (3-hydroxynonate) (PHN). Furthermore, the MCL-PHA typically contain 3-hydroxyhexanote (HHX), 3-hydroxyheptanoate (HH), and/or 3-hydroxydecanoate (HD) [61,62]. The general formula of PHA monomer is illustrated in Figure 6.

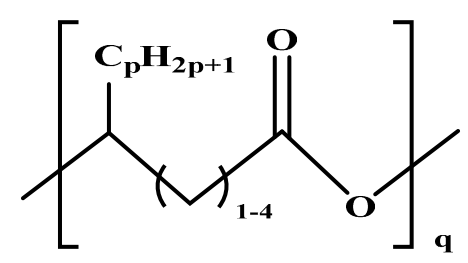

Figure 6. A common chemical structure of polyhydroxyalkanoate monomer, where $p=1$ to 3; yet $p=1$ is the most common monomer, 3-hydroxybutyrate; $q$ can range from 100 to several thousand [61]. Reprinted (adapted) with permission from [61], copyright (2016) American Chemical Society.

Thermal and mechanical properties of the PHA are commonly expressed in terms of glass to rubber transition $\left(T_{\mathrm{g}}\right)$ of the amorphous phase, and this rubbery state of the amorphous phase is generally observed between 19 and $35^{\circ} \mathrm{C}$ [63]. However, PHA is a partially crystalline polymer and its melting temperature belongs to the crystalline phase. Moreover, PHB commonly exhibits a degree of crystallinity in the range of $60 \%$ to $80 \%$; however, the degree of crystallinity decreases to $30 \%$ to $40 \%$ as the copolymerization (PHBV) increases (up to $30 \%$ ). Furthermore, the copolymerization poly(3-hydroxybutyrate-co-4-hydroxybutyrate) (PHBHB) exhibits desirable properties in the field of biomedical and agricultural applications [63].

Nonetheless, during the nanocomposite film fabrication, the crystallinity of the PHB was decreased by increasing the amount of nanoparticles. The crystalline size of PHB substantially decreases in PHB-based nanocomposite films compared with that of the neat PHB film incorporated with $1 \mathrm{wt} \%$ of the single-wall carbon nanotubes [64].

Some organisms are capable of producing different functionalized PHAs, such as hydroxylated, methylated, brominated, and phenyl derivatives [65]. However, further chemical modification of these functional group-containing polyesters (listed in Table 2) expands the application of PHA in the biomedical field [61]. Furthermore, a step-by-step homogeneity of the chemical reaction allows the tailoring of more useful functional monomers on the PHA surface via graft or block copolymerization technique. 
Table 2. Chemical modification of polyhydroxyalkanoate surface via different synthetic routes.

\begin{tabular}{|c|c|c|c|c|}
\hline Functional groups & Synthetic rout & Reaction condzition & Chemically modified PHA & Ref. \\
\hline Mono-hydroxyl & $\begin{array}{l}\text { Transesterification via } \\
\text { acid catalyst }\end{array}$ & $\mathrm{H}_{2} \mathrm{SO}_{4}, \mathrm{MeOH} \mathrm{CH} \mathrm{Cl}_{2}, 100^{\circ} \mathrm{C}$ & & [66] \\
\hline \multirow[t]{2}{*}{ Di-hydroxyl } & $\begin{array}{l}\text { Transesterification via } \\
\text { acid catalyst }\end{array}$ & $\begin{array}{l}\text { 1,4-Butanediol APTS } \\
\text { (para-toluene sulfonic acid } \\
\text { monohydrate) } \mathrm{CHCl}_{3}, 60^{\circ} \mathrm{C}\end{array}$ & & [67] \\
\hline & $\begin{array}{l}\text { Transesterification via } \\
\text { Dibutylene dilaurate catalyst }\end{array}$ & $\begin{array}{l}\text { Ethylene glycol Diglym, } 140{ }^{\circ} \mathrm{C} \\
\text { Dibutylene dilaurate }\end{array}$ & & [68] \\
\hline Branched-poly(ethyleneimine) & Grafting via Michael addition & $\mathrm{CHCl}_{3} 45-50{ }^{\circ} \mathrm{C}$ & & [69] \\
\hline Carboxylic acid & Oxidation & $\begin{array}{l}\text { Osmium tetroxide Oxone, } \\
\mathrm{BuOH}, \mathrm{DMF} 60^{\circ} \mathrm{C}, 8 \mathrm{~h}\end{array}$ & & [70] \\
\hline Epoxidation & Oxyrane addition & $\begin{array}{l}m \text {-Chloroperbenzoic acid, } \\
\mathrm{CHCl}_{3} 20^{\circ} \mathrm{C}, 12 \mathrm{~h}\end{array}$ & & [71] \\
\hline
\end{tabular}


Transesterification is another useful method to modify the PHA surface, in which base or acid catalyst reaction is involved in the modification. Due to the $\mathrm{pH}$ sensitivity of the ester group in PHA, the acid-catalyst reaction is more efficient in producing mono-hydroxylated poly(3-hydroxyoctanoate) (PHO) oligomer than the base-catalyst reaction [69]. This finding is explained by the stability of ester bonds of $\mathrm{PHO}$ at $\mathrm{pH} 10$ and 12 and the immediate occurrence of hydrolysis when $\mathrm{pH}$ was 14 . Thus, PHO oligomers form with the unsaturated end group, which may be the result of the cis-elimination reaction elucidated with PHB [66].

The chemical modification of PHA via the 3-hydroxybutyrate (3HB) and 4-hydroxybutyrate (4HB) content affords $\mathrm{P} 3 / 4 \mathrm{HB}$ polyester-based polymers toward the high crystallinity from soft elastomers [72]. Conversely, the epoxidation of the unsaturated group in PHA achieves specific physical properties and are highly reactive under mild conditions.

The epoxidized PHA can be used for a cross-linking attachment with bioactive substances as an introduction of the ionizable groups. Chen et al. [73] fabricated poly(3-hydroxybutyrate-co3-hydroxyvalerate) (PHBHV)-based nanocomposite film, incorporated with nano-hydroxyapatite. The hindrance of nanofillers to the mobility of polymer segment results in the film tangent of the loss angle $(\tan \delta)$. Nonetheless, improved dynamic mechanical properties and activation energy of the films were observed at the maximum load of nano-hydroxyapatite. Furthermore, the obtained nanocomposite films exhibit a slight increment on their glass transition temperature.

\subsubsection{Protein}

Protein is a natural polymer derived from animals and plants. Collagen, whey protein, casein, egg white, keratin, and fish gelatin are derived from animals, whereas for plant protein, soybean protein, zein (corn protein), and wheat gluten are mainly used in commercial applications [74]. Film-forming ability of protein has been utilized in various industrial applications [75]. Protein films (Table 3) have better oxygen barrier properties and lower water-vapor permeability compared with other nonionic polysaccharide films because of their more polar nature, and more linear (non-ring) structure, and lower free volume [76]. The unique specific interaction capability of these materials with protein DNA, viruses, and other biological structures as well as the accessibility of nanoscale material processing and characterization technique provide a sound method for nanostructured materials in biomedical applications [77].

Surface modification of biomaterials for biomedical applications must satisfy two types of biocompatibility, such that the surface-modified biomaterials elicit the least foreign-body reactions and celland tissue-bonding capabilities [78]. Collagen is regarded as one of the most useful biomaterials, a strong candidate for the surface modification of various substrates, exhibiting a number of advantages [79]. The outstanding performance and biomedical application of this protein biomaterial have induced researcher interests toward synthetic fabrication. Jorge et al. [80] reviewed this system in various aspects, such as synthetic routes, characterization, and self-assembly. Surface modification of protein is a promising technique to achieve more suitable derivative for biomedical applications. For example, proteins have been modified with polyethylene glycol (PEG) and monomethoxy polyethylene glycol-based materials, which are biodegradable. Furthermore, the surface-active nucleophilic sites of the protein coupled with activated hydroxyl group of PEG and cyanuric chloride are used to activate the hydroxyl group of PEG. Accordingly, the PEG-based surface modification creates several disadvantages, such as unsuitability for enzyme-containing reactive-SH group on their active site, toxicity of cyanuric acid and its degradation products.

Alternatively, with succinyl succinates of PEG, activated PEG has also been reported as not becoming an inactive-SH group-dependent enzyme. Furthermore, carbonyl dihymidazole active polymer can also bind with lysine amino groups of protein. Nonetheless, to obtain a highly activated polymer is difficult, resulting in low yield of protein binding. Veronese et al. [81] reported an efficient single-step surface modification of protein, via a reaction between monomethoxy polyethylene glycol and 2,4-richloro-phenylchloroformate or $p$-nitrophenylcloroformate. 
Table 3. Protein films' incorporation of nanomaterials with their properties and applications.

\begin{tabular}{|c|c|c|c|c|}
\hline Protein type & Nano-material & Film properties & Application & Ref \\
\hline \multirow{3}{*}{ WPI } & $\mathrm{TiO}_{2}<1$ wt $\%$ & $\begin{array}{l}\text { Transparent } \\
\text { Oxygen barrier } \\
\text { Improved antimicrobial properties }\end{array}$ & $\begin{array}{l}\text { Industrial: Edible film } \\
\text { Coating and packaging material }\end{array}$ & [82] \\
\hline & $<0.25 \mathrm{wt} \%$ & Promoted florescent and TS & \multirow{2}{*}{ Industrial: Food and cosmetics } & \multirow{2}{*}[83]{} \\
\hline & $>0.25 w t \%$ & $\begin{array}{l}\text { Fluorescent quenching } \\
\text { Reduced TS, WVP, Elongation and light transmittance }\end{array}$ & & \\
\hline \multirow[b]{2}{*}{ Soybean Protein } & & $\begin{array}{l}\text { Poor response for moisture } \\
\text { High rigidity }\end{array}$ & Industrial: Packaging material & {$[84]$} \\
\hline & MMT 5\%-15\% & $\begin{array}{l}\text { Reduce WVP } \\
\text { Improved } \mathrm{MP}, \mathrm{T}_{\mathrm{g}}, \mathrm{DMP} \\
\text { At } \mathrm{pH}=9 \text { and } 5 \mathrm{wt} \% \text { of } \mathrm{MMT}\end{array}$ & Industrial: Packaging material & [85] \\
\hline Zein & Kaolin & $\begin{array}{l}\text { WVP decreased by } 50 \text { wt } \% \text { Kaolin } \\
\text { Reduce oil permeability }\end{array}$ & $\begin{array}{l}\text { Industrial: Barrier coating material for } \\
\text { paper and paper board }\end{array}$ & {$[86]$} \\
\hline Collagen & HA 10 wt \%-30 wt \% & $\begin{array}{l}\text { Lowest contact angle } 36.5 \\
\text { High proliferation rate at } 20 \mathrm{wt} \% \text { of HA }\end{array}$ & Medicinal: Implant & [87] \\
\hline Fish gelatin & MMT 0 wt \%-9 wt \% & $\begin{array}{l}\text { Improved WVP } \\
\text { TS and Elongation maximum at } 5 \mathrm{wt} \% \text { of MMT }\end{array}$ & Industrial: Food & {$[88]$} \\
\hline Egg albumen & - & Improved switching properties & $\begin{array}{l}\text { Industrial: Nonvolatile memory } \\
\text { application (memristor device) }\end{array}$ & [89] \\
\hline Keratin & $\begin{array}{l}\text { Graphene Oxide } \\
0.1 \mathrm{wt} \%-0.5 \mathrm{wt} \%\end{array}$ & $\begin{array}{l}\text { Increased storage modulus up to } 200{ }^{\circ} \mathrm{C} \text { at } 0.1 \mathrm{wt} \% \text { of } \\
\text { graphene oxide }\end{array}$ & Material fabrication & {$[90]$} \\
\hline
\end{tabular}

WVP: Water-vapor permeability; MP: Mechanical properties; DMP: Dynamic mechanical properties; MMT: Montmorillonite; TS: Tensile strength; HA: hydroxyapatite; WPI: Whey protein; $T_{\mathrm{g}}$ : Glass transition temperature. 


\subsection{Synthetic Biodegradable Polymers}

Unlike aromatic polymers, aliphatic polyesters are biodegradable and they lack thermal and mechanical properties. Among the biodegradable polymers, aliphatic polyester-based polymeric structure possesses rapid hydrolytic degradation because of the ester functional group in their main chain. Polycondensation and ring-opening polymerization are the major synthetic routes to prepare the biodegradable polyesters. The ring-opening polymerization method is more useful in producing the high molecular weight polymer than the polycondensation of difunctional monomers. However, aliphatic polyesters are nearly the only high molecular weight biodegradable polymers [91]. In biomedical application, poly(glycolic acid), poly(lactic acid) and their copolymers are the mostly used synthetic polymers.

\subsubsection{Poly(glycolic acid) (PGA)}

Polyglycolide can be obtained via ring-opening polymerization starting with different materials such as cyclic lactone, glycolide (cyclic diester of glycolic acid), and so on. Due to its high degree of crystallization, PGA is hydrophilic and highly degradable but insoluble in most organic solvents except hexafluoroisopropanol [92]. PGA exhibits excellent mechanical properties with high stiffness. Nonetheless, copolymerization of the glycolide with other monomers reduces the stiffness of the resulting fibers [92]. Extrusion, injection, and compression molding as well as the particulate leaching and solvent-casting techniques are used to fabricate PGA-based structures and forms for biomedical application [93].

However, biomedical application of the polyglycolide is limited because of their rapid diacid product form capability. Interestingly, this ability of polyglycolide induced the researchers toward the fabrication of polyglycolide-based surgical sutures.

\subsubsection{Polylactide (PLA)}

Lactide is a cyclic dimer of lactic acid existing in two stereo isomers signified by dexorotary (D) or levorotary (L). L-Lactide is a natural optical isomer and the DL-lactide is a synthetic blend. Polylactide (PLA) can be elastic or tough, flavor resistant, transparent and can be synthesized via polycondensation, the ring-opening polymerization method or melt-solid polycondensation [94]. During PLA fabrication, D-lactic acid or L-lactic acid can be used as difunctional monomer for polycondensation, whereas D-lactide or L-lactide contribute to produce the PLA via ring-opening polymerization. However, PLA has a higher elongation with lower tensile strength. Furthermore, the significantly high degradation rate of PLA is suitable for drug-delivery systems [92].

The steric-shielding effect of methyl- $\left(-\mathrm{CH}_{3}\right)$ group in PLA enhances its hydrophobic nature than PGA. Depending on the isomer, PLA exhibits different physical properties: L-PLA exhibits a semi-crystalline nature with $37 \%$ of crystallinity, whereas DL-PLA is an amorphous polymer. According to the previous studies, degradation depends on the crystalline nature of the polymer materials. Consequently, the degradation order of the PGA and PLA is D,L-PLA < L-PLA < PGA [95]. Consequently, some copolymers of lactide and glycolide have been investigated as bioresorbable implant materials. Moreover, to increase the storage ability of PLA, L-lactide is grafted in the chitosan surface via the ring-opening polymerization technique in the presence of tin catalyst.

\subsubsection{Poly(lactide-co-glycolide) (PLG)}

Glycolide and lactide monomers are used for synthesis of the PLG copolymer, in which monomer ratio and stereo isomers of the lactide are affected on the properties and the applications of the resulting copolymer. The effect includes degradation such that $50 \mathrm{wt} \%$ of glycolide and $50 \mathrm{wt} \%$ DL-lactide-containing PLG degrade faster than either homopolymer [96]. Furthermore, the range of homopolymer properties that extend the base materials (PGA and PLA) and the binding ability with bioactive ceramics, including bioglass particles and hydroxyapatite, are also attractive for several biomedical applications, including drug delivery, the implant device-making process, and so on [97]. 


\subsubsection{Polybutylene Succinate (PBS)}

Polybutylene succinate (PBS) is a member of poly(alkene) dicarboxylate, chemically synthesized via the condensation reaction of succinic acid or adipic acid with ethylene glycol or 1,4-butane diol. PBS exhibits a relatively high melting temperature $\left(T_{\mathrm{m}} \sim 90-113^{\circ} \mathrm{C}\right)$ and mechanical properties compared with widely used polyethylene and polypropylene [98]. Furthermore, some other interesting properties were reviewed by Vroman et al. [95]. The electrical properties of the PBS nanocomposite incorporating multi-walled carbon nanotubes (MWNTs) were reported by Lin et al. [99], in which they found the anti-static nature of the nanocomposite material. Viscoelastic behavior and an improved storage modulus of the PBS nanocomposite were further studied, incorporating organically modified montmorillonite. Moreover, PBS exhibits excellent processing ability in the field of textile into melt blown, nonwoven, flat multifilament, monofilament and split yarn fabrics and plastic into injection-molded products. Nonetheless, inadequate gas barrier, melt viscosity, melt strengths and softness characteristics control the PBS for diverse applications.

PBS can further be copolymerized by adipate to increase the rate of biodegradation. Consequently, glycol and aliphatic dicarboxylic acids are used to synthesize the copolymerized poly(butylene succinate-co-adipate) (PBSA). PBSA exhibits highly similar properties related to low-density polyethylene and used in various applications, including sheet extrusion, monofilaments, multifilament, laminations, injection-molded cutlery, blow-molded containers, and foam cushion [100].

\subsubsection{Poly(vinyl alcohol) $(\mathrm{PVOH})$}

The biodegradation rate of poly(vinyl alcohol) $(\mathrm{PVOH})$ is much higher than the other vinyl polymer, closely related to the poly(enol-ketone). Biodegradation mechanisms of $\mathrm{PVOH}$ occur via the oxidation of hydroxyl group followed by hydrolysis and also influenced by the stereo-chemical configuration of the hydroxyl group of $\mathrm{PVOH}$.

$\mathrm{PVOH}$ is a partial or complete hydrolysate derivative of the polyvinyl acetate because vinyl alcohol monomer nearly exclusively exists as the tautomeric form acetaldehyde [101]. PVOH is the largest water-soluble polymer synthesized globally because of its higher tensile strength and elongation apart from the oxygen and aroma barrier properties. Furthermore, the water-soluble and reactive characteristics make it a potential material for biomedicine and agriculture as well as for the water-treatment field as flocculants [102] and metal-iron remover [103]. Excellent biodegradable and mechanical properties have made the $\mathrm{PVOH}$ an attractive material for biodegradable and disposable plastic substitutes.

\subsubsection{Polyurethanes (PUs)}

Bio-based polyurethanes (PUs) have received considerable attention in the field of environment-friendly manufacturing processes. The polyol plays a major role in producing urethane linkage in PUs with suitable coupling agents. Interestingly, the use of different polyol results in PUs with different properties through producing polyether- and polyester-based PUs. Polyester-based PUs have been largely applied in coating industries because of their biodegradability, wide range of mechanical strength, low temperature, flexibility, toughness, excellent adhesive property, and chemical and corrosion resistance [104].

Inorganic and organic nanoparticles can be used as coating materials for developing PU-based composites with enhanced properties, and thus, such composites can be applied in coating films [95]. PUs are used in a wide range of industries because of their versatile properties; however, PUs are classified into two major categories, namely, polyether- and polyester-based PUs. PUs can be prepared through either cellular or non-cellular products. Non-cellular PUs may be built from a large number of polyether or polyester polyols by reacting with aliphatic or aromatic diisocyantes. On the one hand, the reaction between ethylene oxide and hydroxide or amine-containing initiators such as sucrose, and glycerol, form polyether-based PU monomers. On the other hand, diacid-containing 
initiators produce polyester-based PU monomers. The same results can be obtained by substituting monoglyceride derivative from vegetable oil to ethylene oxide [104]. The lack of biodegradable polyether polyol-based PUs has inspired researchers to continue developing bio-based PUs using polyester polyols. Furthermore, polyester polyol has improved hydrolytic stability, low moisture content (less than $0.1 \%$ ), rapid biodegradable capability, lower acidic number, higher viscosity, higher temperature flexibility, stronger abrasion resistance, and more significant adhesion promotion than polyether polyols, with their enhanced weather capability and strong solvent resistance $[105,106]$. Alkoxylation and esterification are the most possible chemical routes to synthesize polyols [107]. Nonetheless, polyester polyol has a few drawbacks, such as reduction in the storage stability and hydrolytic resistance, and the water evaporation rate of PU dispersions in UV-curable and adhesive applications.

\section{Chemistry of Bio-Based PUs}

Polyester polyol is an alcohol with more than two reactive hydroxyl groups per molecule; among their several distinguished properties, biodegradable capability of the polyester-based PUs is important to overcome the environment effect when compared to polyether-based PUs. However, nearly $90 \%$ of polyether polyols are used in the production of PUs worldwide in recent years and are derived from petrochemical derivatives such as ethylene and propylene oxides [108].

Consequently, researchers and industries are moving towards producing green technology materials under two aspects: using renewable resources and using biodegradable materials. Numerous studies have reported the increasing urgent demands to replace petrochemical derivatives with renewable resources to overcome global warming and the worsening oil crisis [109]. Vegetable oils are used as renewable resources to synthesize the bio-based polyols through esterification. Epoxidized or derivatives (monoglyceride, diclycerides, etc.) of vegetable oils and diacid initiators are also used to synthesize bio-based polyols. However, several chemical routes have been reported to synthesize polyols from epoxide functional groups using a variety of nucleophiles through the epoxide ring-opening mechanism. Depending on the type of nucleophiles, one or more alcohol-functional derivatives can be added to each aliphatic chain.

The chemical synthetic routes of the epoxide ring-opening have been reported based on the SN1 and SN2 reaction mechanisms. Acid catalyst epoxide ring opening follows the SN1 mechanisms, whereas the reaction between epoxide and strong nucleophiles proceeds through the SN2 mechanisms [107]. Caillol et al. [107] reviewed several synthetic routes for polyol preparation through the epoxide ring opening. Ring-opening routes based on carboxylic acids, such as acetic acid, acrylic acid, fatty acid, hexanoic acid, and octanoic acid, produce polyester polyols with interesting properties, particularly biodegradability and as anti-wear lubricants [110,111].

Polyol-making initiators contribute to producing PUs with different characteristics; these initiators are neither aromatic nor aliphatic diacids. Aromatic diacids, such as isophthalic acid (IPA), phthalic acid, and phthalic anhydride, are used to increase the glass transition temperature $\left(T_{\mathrm{g}}\right)$, chemical resistance, and hardness of PUs. Furthermore, IPA is used as a principal aromatic diacid in coating applications [112]. However, these acids are petroleum-based chemicals, and thus, cause environmental degradation. Meanwhile, adipic acid, 1,4-cyclohexanedicarboxylic acid (1,4-CHDA), and succinic acid are used as aliphatic diacids in biodegradable polyol production. Adipic acid is the principal aliphatic acid for preparing polyester polyol via ringopening polymerization. However, 1,4-CHDA exhibits excellent aliphatic and aromatic diacid characteristics. 1,4-CHDA also demonstrate rapid reaction; maintained hardness and flexibility balance; resistance to chemicals and humidity low resin color, improved solubility in methyl ethyl ketone, and stable hydrolytic polyol properties.

Meanwhile, bio-succinic acid is a $100 \%$ bio-based diacid used to synthesize polyester polyols. This acid has $90 \%$ and $50 \%$ carbon footprint with respect to petro-based adipic acid and phthalic anhydride, respectively. It can provide higher glass transition temperature and slightly higher viscosity 
with saturated polyester resins. Succinic acid-based materials are renewable, biodegradable, and are also used to synthesize UV-curable acrylates with commercially available bio-based acrylic acid [105].

\subsection{Nano-Scale Materials}

Nano-scale materials such as nanotubes, nanorods, nanowires and nanoparticles have been increasingly applied in nanotechnology and contribute as value-added materials in bio-based composite fabrication. Nano-scale materials have altered the properties and applications of nanocomposites because of their unique physical and chemical characteristics. The significance and type of the nano-scale material depend on the purpose of the nanocomposites. There are two major types such as inorganic and organic materials that have been used as nanoparticles in the field of bionanocomposite fabrication in recent years. On the one hand there are nano-scaled titanium oxides or cerium oxide doped with silica, alumina, gold, $\mathrm{ZnO}$, and $\mathrm{ZnO} / \mathrm{SiO}_{2}, \mathrm{TiO}_{2}, \mathrm{GeO}_{2}, \mathrm{Cu}_{2} \mathrm{O}, \mathrm{Cr}_{2} \mathrm{O}_{3}, \mathrm{Fe}_{2} \mathrm{O}_{3}$, $\mathrm{PbO}_{2}, \mathrm{CaCO}_{3}, \mathrm{CdS}, \mathrm{Ag}, \mathrm{Pt}$, and $\mathrm{Pd}$ as the inorganic materials used in many applications, especially in the biomedical and tissue-engineering fields [113]. Not only the amount of nanoparticles but also their shape influence the properties of the bionanocomposite materials and are thus reviewed briefly in this paper. Furthermore, there are several nanoparticles such as polystyrene nanosphere, functionalized polystyrene nanosphere, fluorescent nanosphere, nanoparamagnetic particles, and coated polystyrene nanoparticles that are commercially available. Organic materials such as natural fibers, organic liquids, nano-scale cellulose crystals, graphene, and carbon nanotubes are common materials used as fillers in bionanocomposite coating film fabrication. Several studies have mentioned a few versatile methods to combine chitosan with various negatively charged hydroxyapatite microparticles, clay nanoparticles [114] and, most recently, graphene oxide and carbon nanotubes. These versatile methods can be adopted to fabricate free-standing coating films and hydrogels. Saponite is a natural mineral that is also used as an nano-scale material in the form of nanoplatelets to fabricate chitosan-based nanocomposite films [114].

\section{Bionanocomposite Coating Films}

A nanocomposite is characterized by one or more discontinuous phases distributed in one continuous phase. The continuous phase is called the matrix, whereas the discontinuous phase is called the reinforcement or reinforcing material. In the discontinuous phases, one of the phases with components has at least one dimension that is approximately $10^{-9} \mathrm{~m}$. Nano-scaled materials, biopolymers, and cross-linkers act as legitimate members in bionanocomposite fabrications. Moreover, the synthetic routes of bionanocomposites are exploited in three fields: chemical functionalities, self-assembly of copolymer monomer control synthesis, and nanoparticles. Several conventional and novel methods have been reported recently for preparing bionanocomposite coating films, such as suspension-casting, water evaporation, hot pressing, and pressure extrusion [113]. Excessive water evaporation is difficult to manipulate using the suspension-casting and water-evaporation methods. These methods are also typically time consuming, and may take several hours or even a few days [115]. Alternatively, a recent study suggested that the pressure extrusion method could be used to overcome this issue under ambient temperature.

Monolayer and multilayer films are the two major categories of coating films. A monolayer film can be used in coating technology to improve unique properties by modifying the surface of the other materials. On the other hand, multilayer films are composed layer-by-layer formation technology. In this technology, hydrogen bonds and electronic interactions act as driving forces between two layers, which are deposited via solution-dipping or spin-coating. However, as driving forces, non-electrostatic interactions exert an influence when layer-by-layer is assembled for two bio-based materials. De Mesquita et al. [116] also used the layer-by-layer technique to prepare chitosan and CNC-based nanocomposite films as alternative bio-based materials. Poly-(diallyldimethylammonium chloride) and poly-(allylamine hydrochloride) (PAH) have also been used as layer materials incorporated with CNC in the layer-by-layer assembling technique [117], as shown in Figure 7. 


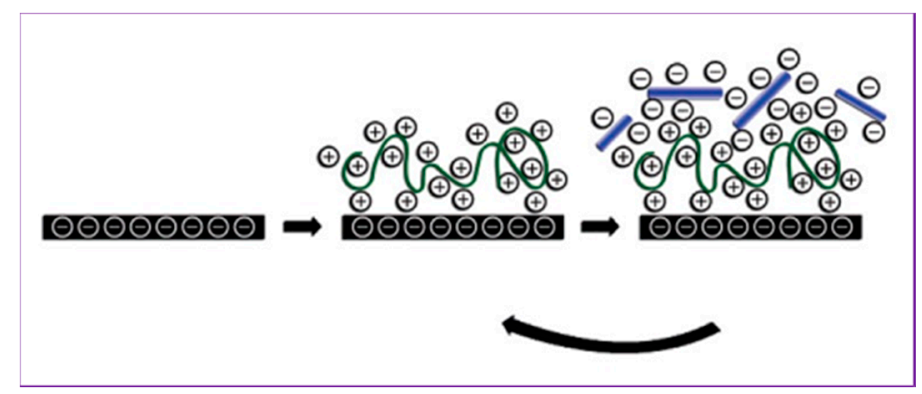

Figure 7. Schematic illustration of the build-up of electrostatically adsorbed multilayered films. Reprinted (adapted) with permission from [117], copyright (2016) American Chemical Society.

\section{Cellulose-Based Nanocomposite Coating Films}

Cellulose is used in many applications because of its outstanding properties, including stiffness, strong reinforcement in composite, excellent dimensional stability [118], water-absorption capability in the food industry, [119] and mechanical properties. Cellulose coatings have received widespread attention in the laboratory because of their use in high-performance nanocomposite films with low environmental impact [120]. These coating films may be used in optical [121], biomedical [122,123], medical sensor [124,125], or electronic applications [126]. The elastic property of cellulose-based materials has been reported. These materials exhibit different values with respect to their composition nature in plant materials. The elastic modules of bulk natural fiber such as wood present $10 \mathrm{GPa}$. Chemical modification has been considered an essential method to endow materials with several unique features $[125,127]$.

Given the large surface area and enhanced hydrogen-bonding capability of fibrils, pre-chemical treatment is typically conducted to destroy the hydrogen bond and to easily conduct chemical modification [128]. Chemically modified cellulose is widely used in various applications, particularly in coating film applications. Cellulose acetate is the first chemically modified cellulose used for filter membranes in water purification [129]. Cellulose acetate has several reliable properties such as high biocompatibility, good desalting properties, moderated hydrophilicity, and high potential flux [130]. However, cellulose acetate has poor fouling resistance caused by the accumulation of biological foulants, such as bacteria and protein cells, on the membrane surface [131]. Nitrocellulose is another form of chemically modified cellulose and is used in the paint industry as an alternative derivative for traditional lacquer and coatings because of the abundance of their raw materials, industrial maturity, and biodegradation. These alternative derivatives overcome increasing indoor and interior environmental [132] and volatile organic compound emission issues [133].

Other chemically modified cellulose derivatives, such as hydroxypropylmethyl cellulose, carboxymethyl cellulose, and methyl cellulose, are obtained by deriving the hydroxymethyl groups at positions 2, 3, or 6 of the hydro-glucose residues. These derivatives exhibit improved solubility and are used in fibers, films, and gel-based materials [134]. Carboxymethyl cellulose can irreversibly bind with positively charged chitosan via complex formation [26]. Cellulose derivative-based films function as effective barriers against $\mathrm{O}_{2} / \mathrm{CO}_{2}$ and demonstrate good tensile resistance $[135,136]$. However, given the hydrophilic nature of cellulose, the prepared cellulose-based edible films do not function as an efficient water-vapor barrier $[136,137]$. Furthermore, adding the prepared CNCs from microcrystalline cellulose via sulfuric acid hydrolysis to PLA or PLA-polyhydroxybutyrate films improve their thermal stability and water permeability [138].

Cellulose sulfate is another type of chemically modified cellulose that is prepared by partial or complete substitution of the 6-hydroxyl groups with sulfate groups. The cellulose sulfate-based films exhibit poor water-vapor barrier capability because of their excellent solubility behavior [139]. However, given the $40 \%$ usage of the petroleum-based chemicals in the packaging industry, this alternative cellulose sulfate is considered a renewable alternative source to conventional 
petroleum-based materials [140]. Cellulose sulfate-based nanocomposite films that incorporate with other molecules such as lipids, glycerols, and oleic acid have extended their application in the field of packaging films. Cellulose sulfate-based hydrocolloid films combined with lipids exhibit better functionality than pure cellulose sulfate films. Glycerol is one of the most popular plasticizers used in cellulose sulfate films to ensure its stability and compatibility with hydrophilic bio-polymers [141].

In cellulose sulfate-oleic acid composite film, oleic acid decreases water content in the emulsion as the intermolecular distance of cellulose sulfate increases. Alkyd resin modified by coconut oil or soybean oil can significantly improve the mechanical properties of coating films; in particular, it reduces the brittleness of carboxymethyl cellulose nitrate films [142]. This type of resin is typically used as an auxiliary film-forming material. Alkyd resins also exhibit good consistency with water.

\section{Application of Bionancomposite Coating Films}

In general, the applications of bionanocomposite coating are ubiquitous in various applications such as in tissue engineering, biomedical, glass coating, food packaging, wood coating, steel coating, drug coating, and fruit coating. However, each coating application has several purposes depending on the demands of the final outcome.

\subsection{Biomedical Application}

Collagen is a biopolymer widely used in medical application, particularly in the fermentation of tissue and organs. Collagen coatings on Ti hard-tissue implants are widely reported in recent works, for their stimulating cellular response [143], increasing remolding [144] that improves bone growth, and bone-implant contact [145]. Collagen is used as film, disk, sheet, shield, sponges, gel, hydrogel and pellet in the drug-delivery system. In biomedical applications, reviews only consider the films' characteristic of the collagen biopolymers. Collagen films have been used for the treatment of tissue infections, specifically infected corneal tissues or liver tissues. Collagen is mainly applied as a membrane with 0.01-0.5 mm film thickness [146]. As the composite matrix, collagen can be combined with a recombinant human morphogenetic protein-2 (rhBMP-2) for implant-bone formation [147]. Nakagawa et al. [148] reported that a collagen-based drug-delivery system (BMP-2 loaded collagen matrix) is highly efficient as a biological onlay implant.

Alternatively, collagen films and disks as gene-delivery systems have many advantages, including isolation of transplanted cells from the host immune system [149] and long-term delivery of therapeutic transgenic product. Collagen sheets are evaluated as a local delivery carrier for cancer treatment; the etoposide (VP-16)-loaded collagen sheets as anti-cancer agents have been revealed to maintain the drug at the target site for a long period [150]. The biodegradable collagen films are not only severed as scaffolds for the survival of transfected fibroblasts, but the composite of collagen and elastin are also suitable for many potential medical applications in reconstructive and plastic surgery [151].

Composite collagen films incorporated with elastin have been reported with various monomer ratios; accordingly, almost consistent tensile values were observed [152]. Tensile strength can be used to evaluate the mechanical strength, resilience activity, endurance, and biocompatibility of the biomaterials. Collagen sponges have been fabricated via isolated pure collagen from bovine skin, followed by swelling at $\mathrm{pH}$ 3.0, which are extremely useful for many types of wounds, mostly severe burns. Furthermore, collagen sponges are a highly efficient material for the recovery of skin and various types of artificial skin incorporation of gelatin [153]. 


\subsection{Tissue-Engineering Application}

A number of natural and synthetic biodegradable polymers are studied in tissue engineering. Pullulan, collagen, chitosan, PHA, PGA, and PLA are used in several tissue-engineering applications, including tissue replacement, bone substitutes, membrane, engineered tissue, scaffolds, guided tissue regeneration, reinforcement and support for weak tissues $[154,155]$. Carboxymethyl pullulan and its conjugation with heparin can inhibit the proliferation of smooth muscle cells in vitro [156]. A cellular bilayer artificial skin was fabricated by Suzuki et al. [157], in which they used silicon as the outer layer and inner collagen sponges. Results showed good long-term postoperative appearance of the split thickness skin graft site. Liu et al. [158] studied chitosan-based bionanocomposite films incorporated with halloysite nanotubes as scaffold materials in tissue engineering. The resultant nanocomposite films exhibit a cytocompatible nature with maximum loading of $10 \%$ halloysite nanotubes. Furthermore, Kim et al. [159] studied the multi-tissue-engineering applications of chitosan-based bionanocomposite. Hajiali et al. [160] used salt-leaching technology to prepare PHA-based nanocomposite scaffold for bone tissue engineering, in which $10 \%$ bioglass nanoparticles were incorporated. Results showed $84 \%$ porosity of the scaffold structure. Moreover, the contribution of synthetic biopolymers and their nanocomposites in tissue-engineering applications have been reviewed by Okamoto et al. [161].

\subsection{UV Protection}

UV radiation is harmful to all living things. Researchers and industries have fabricated various UV ray-protecting products such as sunblock cream and lotions, sunglasses, hats, window protectors and arm protectors and clothes, including rash guards and swimming T-shirts. UVB, which is defined within the range of $315-280 \mathrm{~nm}$, is absorbed by the ozone layer; however, a range of rays generated by UVB reaches the surface of the Earth. UVA has a longer wavelength of 315-400 nm, and its rays reach the surface of the Earth without any deterrent [162]. UV rays can damage the skin through short- and long-term effects. Sunburn, tanning, and photosensitivity (a disease called porphyria caused by UV rays) are considered short-terms effects, whereas long-term effects are highlighted by skin and eye cancer, freckles, solar brown spots (lentiginous), and melanocytic nevi (moles). However, materials used in sun-protection products for specific purposes have commercially high costs and contain non-biodegradable substances.

The sun protection factor (SPF) is one of the important parameters used to measure the UV-blocking capability of materials. This factor, which was introduced by Franz Greiter in 1962, has a unit of $\mathrm{mg} / \mathrm{cm}^{2}$ [163]. On the basis of UV-blocking research on plant materials, high SPF values have been given to Menta piperita leaf and Lycopersicom esculantum fruit that are 8.184 and 5.998, respectively. These plant extracts have significant capability to absorb the UVA (400-315 nm) and UVB (315-280 nm) regions of the UV rays [164]. UV absorbers play a major role in the UV-protecting property of materials. In such materials, the absorbers act as scavengers or singlet oxygen quenchers, and convert the electronic excitation energy into thermal energy. That is, absorbers are excited when they are hit by high-energy short-wave UV radiation and move to a higher energy state. Consequently, the absorbed energy may be dissipated as longer-wave radiation [165]. Several inorganic and organic colorless compounds have been used as UV absorbers in textiles and sunblock lotion. These compounds include 2-ethylhexyl-4-methoxy-cinnamate with high refractive index [166], o-hydroxyl benzophenones, $o$-hydroxyphenyl triazine, and $o$-hydroxy phenyl hydrazine. Furthermore, benzotriazole, hydro benzophenone, and phenyl triazine are primarily used as UV absorbers for coating applications [165].

Inorganic composite materials and compounds also exhibit UV-blocking capability and have been studied in recent years. UV absorbers have been developed for coatings based on the composition of inorganic particles such as titanium oxides or cerium oxide-doped with silica, alumina, organic liquids, iron, $\mathrm{ZnO}$, and $\mathrm{ZnO}-\mathrm{SiO}_{2}$. Their nano-scale shapes also influenced the UV-blocking process. Dumbbell-shaped $\mathrm{ZnO}$ nanorods improve coating application in the textile industry and exhibit wider UV-blocking range (400-280 nm), whereas the UV-blocking range of $\mathrm{ZnO}$ nanosols and $\mathrm{ZnO}$ nanorods 
are within the range of $352-280 \mathrm{~nm}$ and $375-280 \mathrm{~nm}$, respectively. However, a decreasing trend of UV transmittance is observed in cotton textiles coated with $\mathrm{ZnO}-\mathrm{SiO}_{2}$ nanorods [167].

Ching et al. [168] developed the PU/nanosilica composite as a surface protective coating layer for polyethylene greenhouse films. They observed excellent thermal stability with decreasing photo degradation of the composite coating compared with polyethylene that uses $6 \mathrm{wt} \%$ nanosilica. Cotton-based cellulosic fibers and lignins have certain levels of UV-absorbing capability and are used in natural organic coatings [31]. Several studies have reported UV-absorption capability in textile with respect to their nano-scale shape. For example, needle-shaped $\mathrm{ZnO}$ nanorods have the capability to block the UV-transmission of a part of the UVA region $(370-315 \mathrm{~nm})$ and the entire UVB region $(315-250 \mathrm{~nm})$ [169]. Flower-like $\mathrm{ZnO}$ fabricated on cotton cellulose has high absorption capability at a wavelength of $350 \mathrm{~nm}$ [169]. Anatase is one of the three mineral forms of titanium dioxide; it provides UV-blocking capability within the range of 332-280 nm. Textile industries use these materials to enhance the quality of their products with UV-blocking capability.

In the last few decades, researchers have focused on extracting nanocellulose from natural sources, such as cotton, wood, algae, bamboo, sisal, and bacteria because of its high strength, large surface area, and unique optical properties [170]. Nanocellulose-based films exhibit excellent optical transparency, which decreases light scattering within a large portion of light transmittance. Furthermore, the properties of functionalized nanocellulose-based films exhibit improved suitability in their applications such as UV-sensitive polymers, clean windows, contact lens, car windshields, and special biological test containers. These films also have an extraordinarily low thermal expansion coefficient with a range of $12-28.5 \mathrm{ppm} \cdot \mathrm{K}^{-1}$. Nanocellulose-based films are easier to process at high temperatures than plastic substances and possess high transparency, as well as outstanding UV-blocking and biodegradable properties [113]. UV-blocking capability has also been studied on several plants with respect to their parts, including the leaves of Menta piperita, Azadiracha indica, Oscimum sanctum and Aloe vera; the fruits of Lycopersicom esculantum and Carica papaya; and the flowers of Rosa damascene, Crossandra infundibuliformis, Tagetus patula, and Tagetus erecta. A recent study has found that untreated bamboo viscos fiber possesses inherent UV protective properties and demonstrates minimal antimicrobial activity [171].

The nanocomposite nanocellulose films with $\mathrm{ZnO}$ nanomaterials exhibit better UV-protectiong, transparency, and sensitivity capabilities. However, given the high water-binding capacity of nanocellulose, dewatering difficulties and nanocellulose hybrid heterogeneous architectural issues remain during the production process of nanocellulose-based films [113]. Meanwhile, the excessive use of UV-absorbing nanoparticles in textiles is causing ecological problems as a result of the existence of these materials in effluent solutions.

Lignin-based bionanocomposites have significant adhesive [172] and biodegradable properties, and are used as stabilizing agents in aqueous alumina and ceramic suspensions [173]. Lignin acts as a source of aromatic chemicals [174] in PU. Lignin-based nanocomposite coating films are prepared using CNCs and are used in various applications such as medical, biological, optical and sensors, and electronic.

Lignin inherently possesses UV-absorbing capacity [31] and thus, lignin has been used in coating applications with suitable cellulose-to-lignin ratio. The results of UV absorption, transparency, and colorlessness coating have been obtained without the chemical modification of cellulose and lignin fractions. However, novel chemically modified lignins (industrial lignin) [175] such as lignosulfates, kraft lignin, and acetylated lignin have been recently developed [176]. These types of lignins are used for coating applications incorporated with cellulose fiber, commercial derivatives, or nanocellulosic polysaccharides to improve the mechanical resistance, hydrophobicity, and oxygen barrier properties of the fabrication materials. 
CNC-lignin composite coating films are more homogeneous than pure synthetic lignin coating or microcrystalline-lignin coating. These films exhibit various spectroscopic properties in the UV/Visible spectrum. Given the covalently bonded phenolic acid moieties in lignin, CNC-lignin coating films exhibit anti-UV properties that extend up to $340 \mathrm{~nm}$, as illustrated in Figure 8. The properties of these coating films are reported as natural, organic UV absorbent, and visible transparent coating. Furthermore, the mechanical resistance of $\mathrm{CNC}$ and the antibacterial properties of lignin are opened for investigation [31].

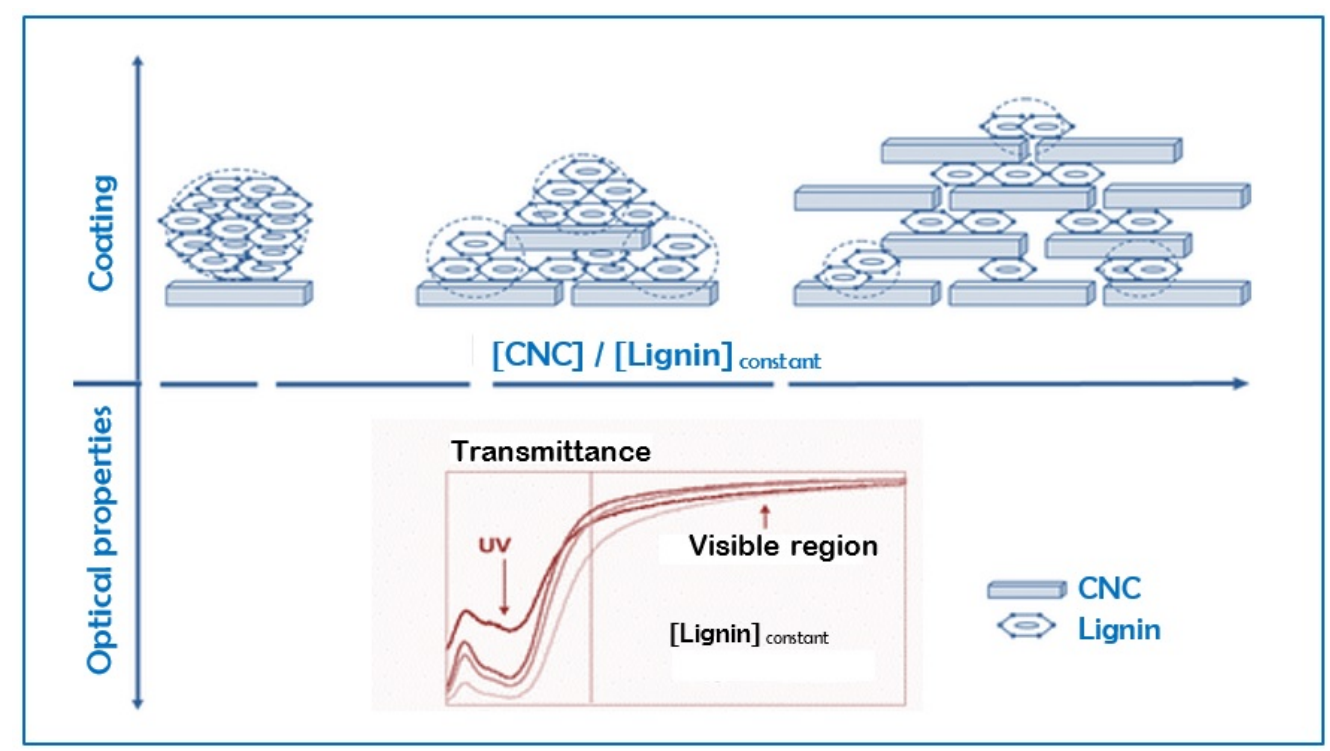

Figure 8. Illustration of the structural arrangement of CNC/lignin nanocomposite coatings and UV-transmittance. Reprinted (adapted) with permission from [31], copyright (2016) American Chemical Society.

\subsection{Antifouling Application}

Cellulose acetate-based membrane surface incorporating with polysaccharides has been fabricated using the layer-by-layer (LBL) technique to study antifouling application. The positive and negative charge functionalities of polysaccharides [177] have been utilized in this type of coating given their diverse chemical compositions [178].

Chitosan and carboxymethyl cellulose on cellulose acetate membrane have also been reported and applied to reduce bovine serum albumin fouling on the membrane $[179,180]$. The layers can be detached by high ionic strength and low $\mathrm{pH}$. This phenomenon demonstrates the reliability of these substances as removable hydrophilic functional coatings for cellulose acetate. However, the protein rejection behavior of this membrane has not been studied extensively.

\subsection{Food Preservation Applications}

Synthetic polymers are used in ubiquitous food packaging applications where they provide permeability to microbial, chemical, organic vapor and oxygen from the environment and allow product display while biopolymers are notorious for their higher water-vapor permeability [181]. An exfoliation of nanoclay (montmorillonite) into polymers creates a maze structure that presents a tortuous path to moving gases, greatly slowing their permeation rate.

Hydroxyl propyl methyl cellulose (HPMC) has been found to be a promising material for edible coatings or films for packaging by Burdock et al. 2007 [182]. Incorporation of chitosan nanofiller into the HPMC matrix improves the mechanical properties and water-vapor permeability while significantly reducing oxygen permeability. Consequently, HPMC-chitosan nanofiller composite films provide potential properties and thus become promising materials for food packaging with better 
shelf-life [183]. Soybean protein nanocomposite films provide an improved elastic modulus and tensile strength with reduced water permeability under ultrasonic treatment with the incorporation of MMT [184].

The compatibility of rosemary oil with chitosan/montmorillonite (MMT) nanocomposite has been confirmed to produce an active bionanocomposite for food packaging. The good interaction between chitosan and MMT can improve the water-vapor permeability, water sensitiveness, and mechanical properties of chitosan films. In addition, chitosan nanocomposites containing rosemary essential oil exhibit antimicrobial properties and high phenol content. These properties make chitosan highly interesting for food preservation.

\subsection{Water-Vapor Barrier}

Packaging plays an important role in the production, transportation, and storage of food or pharmaceutical products. Such products require a material with a high moisture-barrier capacity and potential biodegradability. The common approach to improve the moisture-barrier capacity of nanofibrillated cellulose films for packaging applications is to treat the surfaces of nanofibrillated cellulose substrates with synthetic or bio-based polymers (e.g., whey proteins, PLA, PCL, beeswax) [185,186], or inorganic impermeable particles such as mica [187] or MMT [188] through laminating extrusion, vacuum deposition, and multilayer coating technologies $[189,190]$. Acetylated epoxidized soybean oil is an interesting polymeric material obtained from renewable natural resources. This material contains acrylate functional groups to polymerize/copolymerize easily via free-radical reaction under several initiator systems. Pure acetylated epoxidized soybean oil polymer behaves similarly to an amorphous cross-linked rubber, which fails to produce suitable shapes and to provide high mechanical properties [191] by itself. However, this polymer is expected to have a good moisture barrier-capacity because of its good film-forming and hydrophobic properties.

Several studies have indicated that through controlled polymerization or co-polymerization with other chemical species, this material is able to provide better polymers with optimized properties. These polymers can be used extensively as surface coatings and adhesive agents [192]. To date, acetylated epoxidized soybean oil in cellulose films or fiber networks in packaging production has seldom been used. The film-forming mechanism is attributed to acetylated epoxidized soybean oil, cellulose, and 3-aminopropyltriethoxysilane as constituent nanocomposite materials. Water-vapor transmission rate has been studied with varying of 3-aminopropyltriethoxysilane contents. With a low content (10 wt \% of acetylated epoxidized soybean oil), the reduction in water-vapor transmission rate is insignificant. A continued increase in 3-aminopropyltriethoxysilane content leads to a reduction in water-vapor transmission rate value and to an increase in film hydrophobicity (high contact angle). The best result appears at 3-aminopropyltriethoxysilane $30 \mathrm{wt} \%$, and the resulting water-vapor transmission rate is as low as $1714 \mathrm{~g} / \mathrm{m}^{2}$ at $24 \mathrm{~h}$. Furthermore, the increase in 3-aminopropyltriethoxysilane content does not result in any remarkable reduction.

\section{General Properties of Bionanocomposite Coating Films}

Several studies have been reported on the improvement of the properties, including mechanical properties, barrier properties, functional properties, water solubility [193,194], and thermal stability $[1,22]$ of natural polymer-based bionanocomposite films incorporated with nanoparticles. Furthermore, the combination of antimicrobial/antioxidant compounds, such as essential oils or any natural agents and nanoclay in chitosan film results in acceptable structural reliability and barrier properties. This finding is attributed to the nanocomposite having no combined effect of nanoclay and antimicrobial/antioxidant compounds. For example, chitosan-based nanocomposite with MMT clay particle and rosemary essential oils as antimicrobial/antioxidant compounds exhibit good mechanical properties, water sensitiveness, and improved water vaporization properties [195]. 
The inherent properties of fabricated bionanocomposite coating films are significant for its applications. Mechanical, non-mechanical, and thermal properties are regarded as the major properties of bionanocomposite coating films. However, the physical and chemical characteristics of the constituent materials of bionanocomposite coating films can significantly alter these properties. Mechanical properties do not only depend on the morphology and dimension of the constituent materials, such as nanoparticles and polymer matrix, but also on the formation of the percolating whisker network [196]. The percolation of the whiskers depends on the aspect ratio of the filler, such as sisal nanowhiskers with high aspect ratio. In particular, a filler in polyvinyl acetate-based nanocomposite films can improve mechanical and thermal properties at low fiber loading [196].

Tunicin whiskers with a high aspect ratio as filler constituents of amorphous poly( $\beta$-hydroxyoctanote) (PHO) lead to high mechanical properties of the composite [197]. Similarly, carbon nanotubes with a high aspect ratio as filler exhibit high mechanical properties of the nanocomposite films [198]. Mechanical properties such as tensile strength, elongation at break, and Young's modulus of novel nanocomposite films and the applications of these films are presented in Table 4. Young's modulus linearly increased with microfibrillated cellulose loading by up to $40 \mathrm{wt} \%$ using a phenolic resin [199]. The different types of polymer matrix with the same microfibrillated cellulose loading have shown different values of tensile strength and Young's modulus. For example, the tensile strengths for microfibrillated cellulose with phenol formaldehyde and starch matrix are 370 and $160 \mathrm{MPa}$, whereas their Young's modulus values are 19 and 6.2 GPa, respectively [200].

Non-mechanical properties are also key players in bionanocomposite coating films. These properties mainly include transparency, optical property, flexibility, a light weight, resistance to moisture, adhesion to the substrate, thickness, water-vapor permeability, surface hydrophobicity, oil-holding capacity, chiral nematic and conductivity, antimicrobial activity, UV-blocking properties, and barrier properties. Transparency and optical properties are value-added properties of the bionanocomposite coating films when they are considered to be applied as coating films for auto mobiles and aerospace vehicles as well as for UV-protective window applications. Microfibrillated cellulose has been used with resins in a recent study to fabricate coating films with high transparency; this process can be conducted by eliminating surface scattering. Wood-cellulose-based nanocomposite has also been used as an optically transparent substrate for flexible organic light-emitting displays [201]. Furthermore, an optical transparency analysis has been performed by Ching et al. [202] for a PVA/nanocellulose composite incorporated with nanosilica as a reinforced material. They found a decreasing trend of visible light transmission with an increasing $w t \%$ of nanosilica. 
Table 4. Comparison of mechanical properties of various bionanocomposite films at maximum load. $\left.{ }^{*}\right)$ indicating the unavailability of the relevant data.

\begin{tabular}{|c|c|c|c|c|c|c|}
\hline \multirow{2}{*}{$\begin{array}{l}\text { Constituent } \\
\text { materials of } \\
\text { composites }\end{array}$} & \multicolumn{3}{|c|}{ Properties } & \multirow[b]{2}{*}{$\begin{array}{c}\text { Tensile } \\
\text { strength/(MPa) }\end{array}$} & \multirow{2}{*}{ Applications } & \multirow[b]{2}{*}{ Reference } \\
\hline & $\begin{array}{c}\mathrm{CAL} /\left(^{\circ}\right)^{a} \mathrm{WVP} / \\
\left(10^{-10} \mathrm{~g} / \mathrm{ms} \cdot \mathrm{Pa}\right)^{b}\end{array}$ & Elongation (\%) & $\begin{array}{c}\text { Young's } \\
\text { modulus/(MPa) }\end{array}$ & & & \\
\hline SPI/EDGE/CNC & $53-54^{a}$ & $86-87$ & $48-50$ & $4-6$ & Preliminary & [11] \\
\hline SPI/EDGE/MCNC & $56-57^{a}$ & $78-80$ & $65-70$ & $5-7$ & Preliminary & [11] \\
\hline $\mathrm{CH} / \mathrm{MAC}-\mathrm{CNC}$ & * & $8-11$ & $3500-3700$ & $105-108$ & Preliminary & [203] \\
\hline CH/CNC-Gly & $44-45^{a}$ & $5-6$ & $351-500$ & $8-11$ & Special & [204] \\
\hline $\mathrm{CH} / \mathrm{Gly}-\mathrm{OO}$ & $59-60^{a}$ & 11-12 & $239-420$ & $10-13$ & Special & [204] \\
\hline PVA/GR-CNC & * & $79-85$ & $1432-1550$ & $36-38$ & Reinforcement & [205] \\
\hline $\mathrm{CH} / \mathrm{C}-\mathrm{AgNPs}$ & * & $*$ & $*$ & $*$ & Antimicrobial & [206] \\
\hline $\mathrm{CNC} / \mathrm{ZnO}$ & $88-90^{a}$ & $40-45$ & $6350-7000$ & $55-56$ & Preliminary & [207] \\
\hline $\mathrm{CA} / \mathrm{CNC}$ & $*$ & $16-18$ & $95-1000$ & $30-33$ & Preliminary & [208] \\
\hline PVA/CNWs/CH & * & $126-150$ & $*$ & $62-65$ & Food packaging & [209] \\
\hline AG-CNC/SEO & $2-3^{b}$ & $51-55$ & $46-50$ & $20-22$ & Packaging & [210] \\
\hline CMC/ST-CNC & $4.8-5.2^{b}$ & $19-20$ & $1650-1670$ & $110-116$ & Packaging & [211] \\
\hline $\mathrm{CH} / \mathrm{MMT} / \mathrm{REO}$ & $0.35-0.50^{b}$ & $4-5$ & * & $74-79$ & Preliminary & [37] \\
\hline $\mathrm{SM} / \mathrm{KA}$ & * & $28-32$ & $136-139$ & $5-6$ & Food Packaging & [212] \\
\hline CS/Gly/OA & $94-96^{a}, 15-16^{b}$ & $6-7$ & * & $34-36$ & Packaging & [213] \\
\hline Chi/CH-TA & $*$ & $20-25$ & $1300-1400$ & $50-55$ & Preliminary & [214] \\
\hline $\mathrm{CH} / \mathrm{CNC}-\mathrm{TA}$ & * & $15-25$ & $1700-1750$ & $55-60$ & Preliminary & [215] \\
\hline
\end{tabular}

CAL: Contact angle at (0) time indicating as "a"; WVP: Water vapor permeability indicating as " $\mathrm{b}$ "; SPI: Isolated soybean oil; EDGE: Ethylene glycol diglycidyl ether; CNC: Cellulose nanocrystal; MCNC: Modified CNC; CH: Chitosan; MAC: Methyl adipoly chloride; Gly: Glycerol; OO: Olive oil; PVA: Polyvinyl alcohol; GR: Stabilized graphene; C: Cellulose; Ag: Silver; NPs: Nanoparticles; ZnO: Zinc oxide; CNWs: Cellulose nanowhiskers; AG: Agar; SEO: Savory essential oil; CMC: Carboxymethyl cellulose; ST: Starch;

MMT: Montmorillonite; REO: Rosemary essential oil; SM: Semolina; KA: Kaolin; CS: Cellulose sulfate; OA: Oleic acid; Chi: Chitin; TA: Tannic acid. 


\section{Conclusions}

Bio-based nanocomposite coating films have been used in numerous recent applications with different aspects because of environmental factors and their biodegradability properties. Several recent studies focused on improvement strategies to enhance the quality of bionanocomposite coating film materials. Several naturally occurring low-cost bio-based materials have been on the track to fabricate these coating films through conventional and novel film-producing technologies. These approaches have improved the field of applications as well as the physico-chemical properties and mechanical properties of bionanocomposite coating films. In particular, these approaches have also been active in natural bio-polymer reinforcement, scaffold fabrication, implant device manufacturing, drug delivery and packaging technology.

The future of these coating films does not only depend on the constituent materials, including the scalability of nanoparticles and the stoichiometric ratio of biocomposites, but also on the field in which these films are applied. Furthermore, the future outlook for developing novel coating films with enhanced quality is promising.

Acknowledgments: The authors would like to acknowledge the financial support from High Impact Research MOE Grant UM.C/625/1/HIR/MOE/ENG/52 from the Ministry of Education Malaysia, RP011A-13AET, RU022A-2014, RU019-2015, RG031-15AET and FP053-2015A for the success of this project.

Author Contributions: Mhd Abd Cader Mhd Haniffa and Luqman Chuah Abdullah wrote the paper. Yern Chee Ching and Cheng Hock Chuah initiated and contributed to the scope of the manuscript. Yern Chee Ching and Sin Chew Poh planned the review of the literature and revised the manuscript. Yern Chee Ching and Luqman Chuah Abdullah critically reviewed the manuscript.

Conflicts of Interest: The authors declare no conflict of interest.

\section{References}

1. Darder, M.; Aranda, P.; Ruiz-Hitzky, E. Bionanocomposites: A new concept of ecological, bioinspired, and functional hybrid materials. Adv. Mater. 2007, 19, 1309-1319. [CrossRef]

2. Akintayo, C.O.; Akintayo, E.T.; Ziegler, T. Studies on newly developed urethane modified polyetheramide coatings from albizia benth oil. Prog. Org. Coat. 2011, 71, 89-97. [CrossRef]

3. Chaudhari, A.; Anand, A.; Rajput, S.; Kulkarni, R.; Gite, V. Synthesis, characterization and application of Azadirachta indica juss (neem oil) fatty amides (AIJFA) based polyurethanes coatings: A renewable novel approach. Prog. Org. Coat. 2013, 76, 1779-1785. [CrossRef]

4. Österberg, M.; Peresin, M.S.; Johansson, L.-S.; Tammelin, T. Clean and reactive nanostructured cellulose surface. Cellulose 2013, 20, 983-990. [CrossRef]

5. Dufresne, A. Nanocellulose: A new ageless bionanomaterial. Mater. Today 2013, 16, 220-227. [CrossRef]

6. Habibi, Y.; Lucia, L.A.; Rojas, O.J. Cellulose nanocrystals: Chemistry, self-assembly, and applications. Chem. Rev. 2010, 110, 3479-3500. [CrossRef] [PubMed]

7. Alemdar, A.; Sain, M. Isolation and characterization of nanofibers from agricultural residues-Wheat straw and soy hulls. Bioresour. Technol. 2008, 99, 1664-1671. [CrossRef] [PubMed]

8. Célino, A.; Fréour, S.; Jacquemin, F.; Casari, P. The hygroscopic behavior of plant fibers: A review. Front. Chem. 2013. [CrossRef] [PubMed]

9. Tan, B.K.; Ching, Y.C.; Gan, S.N.; Shaifulazuar, R. Biodegradable mulches based on poly(vinyl alcohol), kenaf fiber, and urea. Bioresource 2015, 10, 5532-5543. [CrossRef]

10. Tan, B.K.; Ching, Y.C.; Poh, S.C.; Luqman, C.A.; Gan, S.N. Review of natural fiber reinforced poly(vinyl alcohol) based composites: Application and opportunity. Polymers 2015, 7, 2205-2222. [CrossRef]

11. Ershad, A.; Yong, K.C.; Ching, Y.C.; Chuah, C.H.; Liou, N.S. Effect of single and double stage chemically treated kenaf fibers on mechanical properties of polyvinyl alcohol film. Bioresource 2015, 10, 822-838.

12. Salminen, T.; Hippi, U.; Salminen, A. Method for the Preparation of NFC Films on Supports. U.S. Patents 20,140,255,688, 11 September 2014.

13. Ching, Y.C.; $\mathrm{Ng}$, T.S. Effect of preparation conditions on cellulose from oil palm empty fruit bunch fiber. Bioresource 2014, 9, 6373-6385. [CrossRef] 
14. Chiappone, A.; Nair, J.R.; Gerbaldi, C.; Zeno, E.; Bongiovanni, R. Cellulose/acrylate membranes for flexible lithium batteries electrolytes: Balancing improved interfacial integrity and ionic conductivity. Eur. Polym. J. 2014, 57, 22-29. [CrossRef]

15. Valentini, L.; Bon, S.B.; Cardinali, M.; Fortunati, E.; Kenny, J.M. Cellulose nanocrystals thin films as gate dielectric for flexible organic field-effect transistors. Mater. Lett. 2014, 126, 55-58. [CrossRef]

16. Sehaqui, H.; Liu, A.; Zhou, Q.; Berglund, L.A. Fast preparation procedure for large, flat cellulose and cellulose/inorganic nanopaper structures. Biomacromolecules 2010, 11, 2195-2198. [CrossRef] [PubMed]

17. Gómez-Estaca, J.; Gómez-Guillén, M.; Fernández-Martín, F.; Montero, P. Effects of gelatin origin, bovine-hide and tuna-skin, on the properties of compound gelatin-chitosan films. Food Hydrocoll. 2011, 25, 1461-1469. [CrossRef]

18. Xu, L.; Huang, Y.-A.; Zhu, Q.-J.; Ye, C. Chitosan in molecularly-imprinted polymers: Current and future prospects. Int. J. Mol. Sci. 2015, 16, 18328-18347. [CrossRef] [PubMed]

19. Rinaudo, M. Chitin and chitosan: Properties and applications. Prog. Polym. Sci. 2006, 31, 603-632. [CrossRef]

20. Rubentheren, V.; Thomas, W.; Ching, Y.C.; Praveena, N. Effects of heat treatment on chitosan nanocomposite film reinforced with nanocrystalline cellulose and tannic acid. Carbohydr. Polym. 2016, 140, $202-208$. [CrossRef] [PubMed]

21. Aider, M. Chitosan application for active bio-based films production and potential in the food industry: Review. LWT Food Sci. Technol. 2010, 43, 837-842. [CrossRef]

22. Wang, S.; Shen, L.; Tong, Y.; Chen, L.; Phang, I.; Lim, P.; Liu, T. Biopolymer chitosan/montmorillonite nanocomposites: Preparation and characterization. Polym. Degrad. Stab. 2005, 90, 123-131. [CrossRef]

23. Xu, Y.; Ren, X.; Hanna, M.A. Chitosan/clay nanocomposite film preparation and characterization. J. Appl. Polym. Sci. 2006, 99, 1684-1691. [CrossRef]

24. Shchipunov, Y. Bionanocomposites: Green sustainable materials for the near future. Pure Appl. Chem. 2012, 84, 2579-2607. [CrossRef]

25. Bourtoom, T.; Chinnan, M.S. Preparation and properties of rice starch-chitosan blend biodegradable film. LWT Food Sci. Technol. 2008, 41, 1633-1641. [CrossRef]

26. Zhang, J.; Chen, X.G.; Li, Y.Y.; Liu, C.S. Self-assembled nanoparticles based on hydrophobically modified chitosan as carriers for doxorubicin. Nanomed. Nanotechnol. Biol. Med. 2007, 3, 258-265. [CrossRef] [PubMed]

27. Shchipunov, Y.; Sarin, S.; Kim, I.; Ha, C.-S. Hydrogels formed through regulated self-organization of gradually charging chitosan in solution of xanthan. Green Chem. 2010, 12, 1187-1195. [CrossRef]

28. Saad, R.; Hawari, J. Grafting of lignin onto nanostructured silica sba-15: Preparation and characterization. J. Porous Mater. 2013, 20, 227-233. [CrossRef]

29. Lora, J.H.; Glasser, W.G. Recent industrial applications of lignin: A sustainable alternative to nonrenewable materials. J. Polym. Environ. 2002, 10, 39-48. [CrossRef]

30. Leplé, J.-C.; Dauwe, R.; Morreel, K.; Storme, V.; Lapierre, C.; Pollet, B.; Naumann, A.; Kang, K.-Y.; Kim, H.; Ruel, K. Downregulation of cinnamoyl-coenzyme a reductase in poplar: Multiple-level phenotyping reveals effects on cell wall polymer metabolism and structure. Plant Cell 2007, 19, 3669-3691. [CrossRef] [PubMed]

31. Hambardzumyan, A.; Foulon, L.; Chabbert, B.; Aguié-Béghin, V.R. Natural organic UV-absorbent coatings based on cellulose and lignin: Designed effects on spectroscopic properties. Biomacromolecules 2012, 13, 4081-4088. [CrossRef] [PubMed]

32. Kim, Y.S.; Kadla, J.F. Preparation of a thermoresponsive lignin-based biomaterial through atom transfer radical polymerization. Biomacromolecules 2010, 11, 981-988. [CrossRef] [PubMed]

33. Jiang, L.; Ma, C.; Zhang, M.-H.; Zhang, X. The graft polymers from different species of lignin and acrylic acid: Synthesis and mechanism study. Int. J. Biol. Macromol. 2014, 63, 43-48.

34. Chen, L.; Ni, Y.; Bian, X.; Qiu, X.; Zhuang, X.; Chen, X.; Jing, X. A novel approach to grafting polymerization of $\varepsilon$-caprolactone onto starch granules. Carbohydr. Polym. 2005, 60, 103-109. [CrossRef]

35. Chung, Y.-L.; Olsson, J.V.; Li, R.J.; Frank, C.W.; Waymouth, R.M.; Billington, S.L.; Sattely, E.S. A renewable lignin-lactide copolymer and application in biobased composites. ACS Sustain. Chem. Eng. 2013, 1, 1231-1238. [CrossRef]

36. Laurichesse, S.; Avérous, L. Synthesis, thermal properties, rheological and mechanical behaviors of lignins-grafted-poly( $\varepsilon$-caprolactone). Polymer 2013, 54, 3882-3890. [CrossRef]

37. Abdollahi, M.; Rezaei, M.; Farzi, G. A novel active bionanocomposite film incorporating rosemary essential oil and nanoclay into chitosan. J. Food Eng. 2012, 111, 343-350. [CrossRef] 
38. Saha, B.C.; Bothast, R.J. Starch conversion by amylases fromaureobasidium pullulans. J. Ind. Microbiol. 1993, 12, 413-416. [CrossRef]

39. Catley, B.J.; Ramsay, A.; Servis, C. Observations on the structure of the fungal extracellular polysaccharide, pullulan. Carbohydr. Res. 1986, 153, 79-86. [CrossRef]

40. Leathers, T.D. Substrate regulation and specificity of amylases from Aureobasidium strain NRRL Y-12,974. FEMS Microbiol. Lett. 1993, 110, 217-221. [CrossRef]

41. Leathers, T.D. Biotechnological production and applications of pullulan. Appl. Microbiol. Biotechnol. 2003, 62, 468-473. [CrossRef] [PubMed]

42. Yuen, K.K. The two-sample trimmed $t$ for unequal population variances. Biometrika 1974, 61, 165-170. [CrossRef]

43. McNeil, B.; Kristiansen, B. Temperature effects on polysaccharide formation by aureobasidium pullulans in stirred tanks. Enzym. Microb. Technol. 1990, 12, 521-526. [CrossRef]

44. Maltsev, V.A.; Wobus, A.M.; Rohwedel, J.; Bader, M.; Hescheler, J. Cardiomyocytes differentiated in vitro from embryonic stem cells developmentally express cardiac-specific genes and ionic currents. Circ. Res. 1994, 75, 233-244. [CrossRef] [PubMed]

45. Fujita, F.; Fukami, K.; Fujimoto, M. Pullulan Aminoalkyl Ether. U.S. Patents 4,167,623, 11 September 1979.

46. Kato, K.; Shiosaka, M. Hydrogenated Pullulan. U.S. Patents 3,931,146, 6 January 1976.

47. Tsuji, K.; Fujimoto, M.; Masuko, F.; Nagase, T. Carboxylated Pullulan and Method for Producing Same. U.S. Patents 4,090,016, 16 May 1978.

48. Hijiya, H.; Shiosaka, M. Shaped Bodies of Pullulan and Their Use. U.S. Patents 3,784,390, 8 January 1974.

49. Bruneel, D.; Schacht, E. Chemical modification of pullulan: 1. Periodate oxidation. Polymer 1993, 34, 2628-2632. [CrossRef]

50. Shibata, M.; Asahina, M.; Teramoto, N.; Yosomiya, R. Chemical modification of pullulan by isocyanate compounds. Polymer 2001, 42, 59-64. [CrossRef]

51. Hasuda, H.; Kwon, O.H.; Kang, I.-K.; Ito, Y. Synthesis of photoreactive pullulan for surface modification. Biomaterials 2005, 26, 2401-2406. [CrossRef] [PubMed]

52. Kuroda, K.; Fujimoto, K.; Sunamoto, J.; Akiyoshi, K. Hierarchical self-assembly of hydrophobically modified pullulan in water: Gelation by networks of nanoparticles. Langmuir 2002, 18, 3780-3786. [CrossRef]

53. Fernandes, S.C.; Sadocco, P.; Causio, J.; Silvestre, A.J.; Mondragon, I.; Freire, C.S. Antimicrobial pullulan derivative prepared by grafting with 3-aminopropyltrimethoxysilane: Characterization and ability to form transparent films. Food Hydrocoll. 2014, 35, 247-252. [CrossRef]

54. Na, K.; Lee, T.B.; Park, K.-H.; Shin, E.-K.; Lee, Y.-B.; Choi, H.-K. Self-assembled nanoparticles of hydrophobically-modified polysaccharide bearing vitamin $\mathrm{h}$ as a targeted anti-cancer drug delivery system. Eur. J. Pharm. Sci. 2003, 18, 165-173. [CrossRef]

55. Introzzi, L. Development of High Performance Biopolymer Coatings for Food Packaging Applications. Ph.D. Thesis, University of Milan, Milan, Italy, 2012.

56. Trovatti, E.; Fernandes, S.C.; Rubatat, L.; Freire, C.S.; Silvestre, A.J.; Neto, C.P. Sustainable nanocomposite films based on bacterial cellulose and pullulan. Cellulose 2012, 19, 729-737. [CrossRef]

57. Pinto, R.J.; Almeida, A.; Fernandes, S.C.; Freire, C.S.; Silvestre, A.J.; Neto, C.P.; Trindade, T. Antifungal activity of transparent nanocomposite thin films of pullulan and silver against Aspergillus niger. Colloids Surf. B Biointerfaces 2013, 103, 143-148. [CrossRef] [PubMed]

58. Coseri, S.; Spatareanu, A.; Sacarescu, L.; Rimbu, C.; Suteu, D.; Spirk, S.; Harabagiu, V. Green synthesis of the silver nanoparticles mediated by pullulan and 6-carboxypullulan. Carbohydr. Polym. 2015, 116, 9-17. [CrossRef] [PubMed]

59. Reddy, C.; Ghai, R.; Kalia, V.C. Polyhydroxyalkanoates: An overview. Bioresour. Technol. 2003, 87, 137-146. [CrossRef]

60. Anderson, A.J.; Dawes, E.A. Occurrence, metabolism, metabolic role, and industrial uses of bacterial polyhydroxyalkanoates. Microbiol. Rev. 1990, 54, 450-472. [PubMed]

61. Kai, D.; Loh, X.J. Polyhydroxyalkanoates: Chemical modifications toward biomedical applications. ACS Sustain. Chem. Eng. 2013, 2, 106-119. [CrossRef]

62. Chen, G.-Q.; Wu, Q. The application of polyhydroxyalkanoates as tissue engineering materials. Biomaterials 2005, 26, 6565-6578. [CrossRef] [PubMed] 
63. Crétois, R.; Delbreilh, L.; Dargent, E.; Follain, N.; Lebrun, L.; Saiter, J. Dielectric relaxations in polyhydroxyalkanoates/organoclay nanocomposites. Eur. Polym. J. 2013, 49, 3434-3444. [CrossRef]

64. Yun, S.I.; Gadd, G.E.; Latella, B.A.; Lo, V.; Russell, R.A.; Holden, P.J. Mechanical properties of biodegradable polyhydroxyalkanoates/single wall carbon nanotube nanocomposite films. Polym. Bull. 2008, 61, 267-275. [CrossRef]

65. Kim, Y.B.; Rhee, Y.H. Evaluation of various carbon substrates for the biosynthesis of polyhydroxyalkanoates bearing functional groups by Pseudomonas putida. Int. J. Biol. Macromol. 2000, 28, 23-29. [CrossRef]

66. Timbart, L.; Renard, E.; Tessier, M.; Langlois, V. Monohydroxylated poly(3-hydroxyoctanoate) oligomers and its functionalized derivatives used as macroinitiators in the synthesis of degradable diblock copolyesters. Biomacromolecules 2007, 8, 1255-1265. [CrossRef] [PubMed]

67. Saad, G.R.; Lee, Y.; Seliger, H. Synthesis and thermal properties of biodegradable poly(ester-urethane)s based on chemo-synthetic poly[(R,S)-3-hydroxybutyrate]. Macromol. Biosci. 2001, 1, 91-99. [CrossRef]

68. Hirt, T.D.; Neuenschwander, P.; Suter, U.W. Telechelic diols from poly[(R)-3-hydroxybutyric acid] and poly\{[(R)-3-hydroxybutyric acid]-co-[(R)-3-hydroxyvaleric acid]\}. Macromol. Chem. Phys. 1996, 197, 1609-1614. [CrossRef]

69. Zhou, L.; Chen, Z.; Chi, W.; Yang, X.; Wang, W.; Zhang, B. Mono-methoxy-poly(3-hydroxybutyrateco-4-hydroxybutyrate)-graft-hyper-branched polyethylenimine copolymers for sirna delivery. Biomaterials 2012, 33, 2334-2344. [CrossRef] [PubMed]

70. Stigers, D.J.; Tew, G.N. Poly(3-hydroxyalkanoate)s functionalized with carboxylic acid groups in the side chain. Biomacromolecules 2003, 4, 193-195. [CrossRef] [PubMed]

71. Park, W.H.; Lenz, R.W.; Goodwin, S. Epoxidation of bacterial polyesters with unsaturated side chains. II. Rate of epoxidation and polymer properties. J. Polym. Sci. Part A Polym. Chem. 1998, 36, 2381-2387. [CrossRef]

72. Pan, J.; Li, G.; Chen, Z.; Chen, X.; Zhu, W.; Xu, K. Alternative block polyurethanes based on poly(3-hydroxybutyrate-co-4-hydroxybutyrate) and poly(ethylene glycol). Biomaterials 2009, 30, 2975-2984. [CrossRef] [PubMed]

73. Chen, D.; Tang, C.; Chan, K.; Tsui, C.; Peter, H.; Leung, M.C.; Uskokovic, P. Dynamic mechanical properties and in vitro bioactivity of PHBHV/HA nanocomposite. Compos. Sci. Technol. 2007, 67, 1617-1626. [CrossRef]

74. Lee, S.; Lee, M.; Song, K. Effect of $\gamma$-irradiation on the physicochemical properties of gluten films. Food Chem. 2005, 92, 621-625. [CrossRef]

75. Cuq, B.; Gontard, N.; Guilbert, S. Proteins as agricultural polymers for packaging production. Cereal Chem. 1998, 75, 1-9. [CrossRef]

76. Miller, K.; Krochta, J. Oxygen and aroma barrier properties of edible films: A review. Trends Food Sci. Technol. 1997, 8, 228-237. [CrossRef]

77. Narayan, R.J.; Kumta, P.N.; Sfeir, C.; Lee, D.-H.; Choi, D.; Olton, D. Nanostructured ceramics in medical devices: Applications and prospects. JOM 2004, 56, 38-43. [CrossRef]

78. Ikada, Y. Surface modification of polymers for medical applications. Biomaterials 1994, 15, 725-736. [CrossRef]

79. Lee, C.H.; Singla, A.; Lee, Y. Biomedical applications of collagen. Int. J. Pharm. 2001, 221, 1-22. [CrossRef]

80. Fallas, J.A.; O'Leary, L.E.; Hartgerink, J.D. Synthetic collagen mimics: Self-assembly of homotrimers, heterotrimers and higher order structures. Chem. Soc. Rev. 2010, 39, 3510-3527. [CrossRef] [PubMed]

81. Veronese, F.; Largajolli, R.; Boccu, E.; Benassi, C.; Schiavon, O. Surface modification of proteins activation of monomethoxy-polyethylene glycols by phenylchloroformates and modification of ribonuclease and superoxide dismutase. Appl. Biochem. Biotechnol. 1985, 11, 141-152. [CrossRef] [PubMed]

82. Sothornvit, R.; Krochta, J.M. Plasticisers in edible films and coatings. In Innovations in Food Packaging; Han, J.H., Ed.; Elsevier Publishers: New York, NY, USA, 2005; pp. 403-428.

83. Li, Y.; Jiang, Y.; Liu, F.; Ren, F.; Zhao, G.; Leng, X. Fabrication and characterization of $\mathrm{TiO}_{2} /$ whey protein isolate nanocomposite film. Food Hydrocoll. 2011, 25, 1098-1104. [CrossRef]

84. Tian, H.; Liu, D.; Zhang, L. Structure and properties of soy protein films plasticized with hydroxyamine. J. Appl. Polym. Sci. 2009, 111, 1549-1556. [CrossRef]

85. Kumar, P.; Sandeep, K.; Alavi, S.; Truong, V.-D.; Gorga, R.E. Preparation and characterization of bio-nanocomposite films based on soy protein isolate and montmorillonite using melt extrusion. J. Food Eng. 2010, 100, 480-489. [CrossRef]

86. Rissa, K.; Lepistö, T.; Yrjölä, K. Effect of kaolin content on structure and functional properties of water-based coatings. Prog. Org. Coat. 2006, 55, 137-141. [CrossRef] 
87. Teng, S.-H.; Lee, E.-J.; Park, C.-S.; Choi, W.-Y.; Shin, D.-S.; Kim, H.-E. Bioactive nanocomposite coatings of collagen/hydroxyapatite on titanium substrates. J. Mater. Sci. Mater. Med. 2008, 19, 2453-2461. [CrossRef] [PubMed]

88. Bae, H.J. Fish Gelatin-Nanoclay Composite Film. Mechanical and Physical Properties, Effect of Enzyme Cross-Linking, and as a Functional Film Layer; ProQuest: Clemson, SC, USA, 2007.

89. Chen, Y.-C.; Yu, H.-C.; Huang, C.-Y.; Chung, W.-L.; Wu, S.-L.; Su, Y.-K. Nonvolatile bio-memristor fabricated with egg albumen film. Sci. Rep. 2015. [CrossRef] [PubMed]

90. Rodríguez-González, C.; Martínez-Hernández, A.L.; Castaño, V.M.; Kharissova, O.V.; Ruoff, R.S.; Velasco-Santos, C. Polysaccharide nanocomposites reinforced with graphene oxide and keratin-grafted graphene oxide. Ind. Eng. Chem. Res. 2012, 51, 3619-3629. [CrossRef]

91. Chandra, R.; Rustgi, R. Biodegradable polymers. Prog. Polym. Sci. 1998, 23, 1273-1335. [CrossRef]

92. Middleton, J.C.; Tipton, A.J. Synthetic biodegradable polymers as orthopedic devices. Biomaterials 2000, 21, 2335-2346. [CrossRef]

93. Gunatillake, P.; Mayadunne, R.; Adhikari, R. Recent developments in biodegradable synthetic polymers. Biotechnol. Annu. Rev. 2006, 12, 301-347. [PubMed]

94. Maharana, T.; Mohanty, B.; Negi, Y. Melt-solid polycondensation of lactic acid and its biodegradability. Prog. Polym. Sci. 2009, 34, 99-124. [CrossRef]

95. Vroman, I.; Tighzert, L. Biodegradable polymers. Materials 2009, 2, 307-344. [CrossRef]

96. Lendlein, A. Polymere als implantatwerkstoffe. Chem. Unserer Zeit 1999, 33, 279-295. [CrossRef]

97. Miller, R.A.; Brady, J.M.; Cutright, D.E. Degradation rates of oral resorbable implants (polylactates and polyglycolates): Rate modification with changes in PLA/PGA copolymer ratios. J. Biomed. Mater. Res. 1977, 11, 711-719. [CrossRef] [PubMed]

98. Chen, C.; Yang, C.; Chen, M.; Shih, Y.; Hsu, H.; Lu, S. Synthesis and characterization of novel poly(butylene succinate-co-2-methyl-1,3-propylene succinate)s. Exp. Polym. Lett. 2011, 5, 284-294. [CrossRef]

99. Lin, C.-S.; Shih, Y.-F.; Jeng, R.-J.; Dai, S.A.; Lin, J.-J.; Lee, C.-C. Nanocomposites with enhanced electrical properties based on biodegradable poly(butylene succinate) and polyetheramine modified carbon nanotube. J. Taiwan Inst. Chem. Eng. 2012, 43, 322-328. [CrossRef]

100. Steeves, D.M.; Farrell, R.; Ratto, J.A. Investigation of polybutylene succinate-co-adipate (PBSA)/montmorillonite layered silicate (MLS) melt-processed nanocomposites. J. Biobased Mater. Bioenergy 2007, 1, 94-108.

101. Ramaraj, B. Crosslinked poly(vinyl alcohol) and starch composite films. II. Physicomechanical, thermal properties and swelling studies. J. Appl. Polym. Sci. 2007, 103, 909-916. [CrossRef]

102. Yan, Y.; Glover, S.; Jameson, G.; Biggs, S. The flocculation efficiency of polydisperse polymer flocculants. Int. J. Miner. Proc. 2004, 73, 161-175. [CrossRef]

103. Lv, X.; Jiang, G.; Xue, X.; Wu, D.; Sheng, T.; Sun, C.; Xu, X. $\mathrm{Fe}^{0}-\mathrm{Fe}_{3} \mathrm{O}_{4}$ nanocomposites embedded polyvinyl alcohol/sodium alginate beads for chromium (VI) removal. J. Hazard. Mater. 2013, 262, 748-758. [CrossRef] [PubMed]

104. Ismail, E.A.; Motawie, A.; Sadek, E. Synthesis and characterization of polyurethane coatings based on soybean oil-polyester polyols. Egypt. J. Pet. 2011, 20, 1-8. [CrossRef]

105. Ching, Y.C.; Iskander, I.Y. Effect of polyurethane/nanosilica composites coating on thermo-mechanical properties of polyethylene film. Mater. Technol. 2012, 27, 113-115. [CrossRef]

106. Ching, Y.C.; Chen, Y.C.; Iskandar, I.Y. Mechanical properties changes of nanosilica filled solventborne polyamide binder after accelerated weathering exposure weathering. Adv. Sci. Lett. 2012, 13, 575-578.

107. Caillol, S.; Desroches, M.; Boutevin, G.; Loubat, C.; Auvergne, R.; Boutevin, B. Synthesis of new polyester polyols from epoxidized vegetable oils and biobased acids. Eur. J. Lipid Sci. Technol. 2012, 114, 1447-1459. [CrossRef]

108. Rozman, H.; Yeo, Y.; Tay, G.; Abubakar, A. The mechanical and physical properties of polyurethane composites based on rice husk and polyethylene glycol. Polym. Test. 2003, 22, 617-623. [CrossRef]

109. Velayutham, T.S.; Majid, W.A.; Ahmad, A.; Kang, G.Y.; Gan, S. Synthesis and characterization of polyurethane coatings derived from polyols synthesized with glycerol, phthalic anhydride and oleic acid. Prog. Org. Coat. 2009, 66, 367-371. [CrossRef]

110. Lee, A. Synthesis of polyurethane from one hundred percent sustainable natural materials through non-isocyanate reactions. Master's Thesis, Georgia Institute of Technology, Atlanta, GA, USA, 2014. 
111. Lalevée, J.; Mokbel, H.; Fouassier, J.-P. Recent developments of versatile photoinitiating systems for cationic ring opening polymerization operating at any wavelengths and under low light intensity sources. Molecules 2015, 20, 7201-7221. [CrossRef] [PubMed]

112. Liu, N.-I. Linear Low Density Polyethylene Impact Modifier for Thermoplastic Polyesters. U.S. Patents 4,476,274, 9 October 1984.

113. Jiang, Y.; Song, Y.; Miao, M.; Cao, S.; Feng, X.; Fang, J.; Shi, L. Transparent nanocellulose hybrid films functionalized with $\mathrm{ZnO}$ nanostructures for UV-blocking. J. Mater. Chem. C 2015, 3, 6717-6724. [CrossRef]

114. Shchipunov, Y.A.; Sarin, S.; Silant'ev, V.; Postnova, I. Self-organization in the chitosan-clay nanoparticles system regulated through polysaccharide macromolecule charging. 2. Films. Colloid J. 2012, 74, 636-644. [CrossRef]

115. Habibi, Y.; Hoeger, I.; Kelley, S.S.; Rojas, O.J. Development of langmuir-schaeffer cellulose nanocrystal monolayers and their interfacial behaviors. Langmuir 2009, 26, 990-1001. [CrossRef] [PubMed]

116. De Mesquita, J.P.; Donnici, C.L.; Pereira, F.V. Biobased nanocomposites from layer-by-layer assembly of cellulose nanowhiskers with chitosan. Biomacromolecules 2010, 11, 473-480. [CrossRef] [PubMed]

117. Cranston, E.D.; Gray, D.G. Morphological and optical characterization of polyelectrolyte multilayers incorporating nanocrystalline cellulose. Biomacromolecules 2006, 7, 2522-2530. [CrossRef] [PubMed]

118. Czaja, W.; Romanovicz, D.; Malcolm Brown, R. Structural investigations of microbial cellulose produced in stationary and agitated culture. Cellulose 2004, 11, 403-411. [CrossRef]

119. Shi, Z.; Zhang, Y.; Phillips, G.O.; Yang, G. Utilization of bacterial cellulose in food. Food Hydrocoll. 2014, 35, 539-545. [CrossRef]

120. Fortunati, E.; Puglia, D.; Luzi, F.; Santulli, C.; Kenny, J.M.; Torre, L. Binary PVA bio-nanocomposites containing cellulose nanocrystals extracted from different natural sources: Part I. Carbohydr. Polym. 2013, 97, 825-836. [CrossRef] [PubMed]

121. Podsiadlo, P.; Sui, L.; Elkasabi, Y.; Burgardt, P.; Lee, J.; Miryala, A.; Kusumaatmaja, W.; Carman, M.R.; Shtein, M.; Kieffer, J. Layer-by-layer assembled films of cellulose nanowires with antireflective properties. Langmuir 2007, 23, 7901-7906. [CrossRef] [PubMed]

122. Wang, X.; Yang, K.; Tao, S.; Xing, B. Sorption of aromatic organic contaminants by biopolymers: Effects of $\mathrm{pH}$, copper (II) complexation, and cellulose coating. Environ. Sci. Technol. 2007, 41, 185-191. [CrossRef] [PubMed]

123. Juntaro, J.; Pommet, M.; Kalinka, G.; Mantalaris, A.; Shaffer, M.S.; Bismarck, A. Creating hierarchical structures in renewable composites by attaching bacterial cellulose onto sisal fibers. Adv. Mater. 2008, 20, 3122-3126. [CrossRef]

124. Mohr, G.J. Polymers for optical sensors. In Optical Chemical Sensors; Springer: Dordrecht, The Netherlands, 2006; pp. 297-321.

125. Shukla, S. Synthesis of polyaniline grafted cellulose suitable for humidity sensing. Indian J. Eng. Mater. Sci. 2012, 19, 417-420.

126. Choh, J.L.; Ching, Y.C.; Gan, S.N.; Shaifulazuar, R.; Sabariah, J. Effects of oil palm empty fruit bunch fiber on electrical and mechanical properties of conductive filler reinforced polymer composite. Bioresource 2016, 11, 913-928. [CrossRef]

127. Peltzer, M.; Pei, A.; Zhou, Q.; Berglund, L.; Jiménez, A. Surface modification of cellulose nanocrystals by grafting with poly(lactic acid). Polym. Int. 2014, 63, 1056-1062. [CrossRef]

128. Missoum, K.; Belgacem, M.N.; Barnes, J.-P.; Brochier-Salon, M.-C.; Bras, J. Nanofibrillated cellulose surface grafting in ionic liquid. Soft Matter 2012, 8, 8338-8349. [CrossRef]

129. Kutowy, O.; Sourirajan, S. Cellulose acetate ultrafiltration membranes. J. Appl. Polym. Sci. 1975, 19, $1449-1460$. [CrossRef]

130. Han, B.; Zhang, D.; Shao, Z.; Kong, L.; Lv, S. Preparation and characterization of cellulose acetate/carboxymethyl cellulose acetate blend ultrafiltration membranes. Desalination 2013, 311, 80-89. [CrossRef]

131. Koseoglu-Imer, D.Y.; Dizge, N.; Koyuncu, I. Enzymatic activation of cellulose acetate membrane for reducing of protein fouling. Colloids Surf. B Biointerfaces 2012, 92, 334-339. [CrossRef] [PubMed]

132. Vardanyan, V.; Galstian, T.; Riedl, B. Characterization of cellulose nanocrystals dispersion in varnishes by backscattering of laser light. J. Coat. Technol. Res. 2015, 12, 647-656. [CrossRef] 
133. Haag, H.F. Low-VOC waterborne coatings for wood based on nitrocellulose-acrylic latex. JCT 1992, 64, 19-26.

134. Clasen, C.; Kulicke, W.-M. Determination of viscoelastic and rheo-optical material functions of water-soluble cellulose derivatives. Prog. Polym. Sci. 2001, 26, 1839-1919. [CrossRef]

135. Ortega-Toro, R.; Jiménez, A.; Talens, P.; Chiralt, A. Properties of starch-hydroxypropyl methylcellulose based films obtained by compression molding. Carbohydr. Polym. 2014, 109, 155-165. [CrossRef] [PubMed]

136. Ching, Y.C.; Md. Ershad, A.; Luqman, C.A.; Choo, K.W.; Yong, C.K.; Sabariah, J.J.; Chuah, C.H.; Liou, N.S. Rheological properties of cellulose nanocrystal-embedded polymer composites: A review. Cellulose 2016, 23, 1011-1030. [CrossRef]

137. Goh, K.Y.; Ching, Y.C.; Chuah, C.H.; Luqman, C.A.; Liou, N.S. Individualization of microfibrillated celluloses from oil palm empty fruit bunch: Comparative studies between acid hydrolysis and ammonium persulfate oxidation. Cellulose 2016, 23, 379-390. [CrossRef]

138. Arrieta, M.P.; Fortunati, E.; Dominici, F.; López, J.; Kenny, J.M. Bionanocomposite films based on plasticized PLA-PHB/cellulose nanocrystal blends. Carbohydr. Polym. 2015, 121, 265-275. [CrossRef] [PubMed]

139. Chen, G.; Liu, B.; Zhang, B. Characterization of composite hydrocolloid film based on sodium cellulose sulfate and cassava starch. J. Food Eng. 2014, 125, 105-111. [CrossRef]

140. Pilla, S. Engineering applications of bioplastics and biocomposites-An overview. In Handbook of Bioplastics and Biocomposites Engineering Applications; Scrivener Publishing: Salem, MA, USA, 2011; pp. 1-15.

141. Chillo, S.; Flores, S.; Mastromatteo, M.; Conte, A.; Gerschenson, L.; del Nobile, M. Influence of glycerol and chitosan on tapioca starch-based edible film properties. J. Food Eng. 2008, 88, 159-168. [CrossRef]

142. Duan, H.; Shao, Z.; Zhao, M.; Zhou, Z. Preparation and properties of environmental-friendly coatings based on carboxymethyl cellulose nitrate ester and modified alkyd. Carbohydr. Polym. 2016, 137, 92-99. [CrossRef] [PubMed]

143. Kim, H.W.; Li, L.H.; Lee, E.J.; Lee, S.H.; Kim, H.E. Fibrillar assembly and stability of collagen coating on titanium for improved osteoblast responses. J. Biomed. Mater. Res. A 2005, 75, 629-638. [CrossRef] [PubMed]

144. Rammelt, S.; Illert, T.; Bierbaum, S.; Scharnweber, D.; Zwipp, H.; Schneiders, W. Coating of titanium implants with collagen, RGD peptide and chondroitin sulfate. Biomaterials 2006, 27, 5561-5571. [CrossRef] [PubMed]

145. Morra, M.; Cassinelli, C.; Meda, L.; Fini, M.; Giavaresi, G.; Giardino, R. Surface analysis and effects on interfacial bone microhardness of collagen-coated titanium implants: A rabbit model. Int. J. Oral Maxillofac. Implant. 2005, 20, 23-30.

146. Rubin, A.L.; Stenzel, K.H.; Miyata, T.; White, M.J.; Dunn, M. Collagen as a vehicle for drug delivery. J. Clin. Pharmacol. New Drugs 1973, 13, 309-312. [CrossRef]

147. Murata, M.; Maki, F.; Sato, D.; Shibata, T.; Arisue, M. Bone augmentation by onlay implant using recombinant human BMP-2 and collagen on adult rat skull without periosteum. Clin. Oral Implant. Res. 2000, 11, 289-295. [CrossRef]

148. Nakagawa, T.; Tagawa, T. Ultrastructural study of direct bone formation induced by BMPs-collagen complex implanted into an ectopic site. Oral Dis. 2000, 6, 172-179. [CrossRef] [PubMed]

149. Liu, H.-W.; Ofosu, F.A.; Chang, P.L. Expression of human factor IX by microencapsulated recombinant fibroblasts. Hum. Gene Ther. 1993, 4, 291-301. [CrossRef] [PubMed]

150. Sato, H.; Kitazawa, H.; Adachi, I.; Horikoshi, I. Microdialysis assessment of microfibrous collagen containing a P-glycoprotein-mediated transport inhibitor, cyclosporine A, for local delivery of etoposide. Pharm. Res. 1996, 13, 1565-1569. [CrossRef] [PubMed]

151. Vardaxis, N.; Boon, M.; Ruijgrok, J. Calcification of cross-linked collagen-elastin membrane implants in vivo and their proposed use in bone regeneration. Biomaterials 1996, 17, 1489-1497. [CrossRef]

152. Meaney, D.F. Mechanical properties of implantable biomaterials. Clin. Podiatr. Med. Surg. 1995, 12, $363-384$. [PubMed]

153. Koide, M.; Osaki, K.; Konishi, J.; Oyamada, K.; Katakura, T.; Takahashi, A.; Yoshizato, K. A new type of biomaterial for artificial skin: Dehydrothermally cross-linked composites of fibrillar and denatured collagens. J. Biomed. Mater. Res. 1993, 27, 79-87. [CrossRef] [PubMed]

154. Chen, G.-Q.; Wu, Q. Microbial production and applications of chiral hydroxyalkanoates. Appl. Microbiol. Biotechnol. 2005, 67, 592-599. [CrossRef] [PubMed]

155. Williams, S.F.; Martin, D.P.; Horowitz, D.M.; Peoples, O.P. PHA applications: Addressing the price performance issue: I. Tissue engineering. Int. J. Biol. Macromol. 1999, 25, 111-121. [CrossRef] 
156. Na, K.; Shin, D.; Yun, K.; Park, K.-H.; Lee, K.C. Conjugation of heparin into carboxylated pullulan derivatives as an extracellular matrix for endothelial cell culture. Biotechnol. Lett. 2003, 25, 381-385. [CrossRef] [PubMed]

157. Suzuki, S.; Kawai, K.; Ashoori, F.; Morimoto, N.; Nishimura, Y.; Ikada, Y. Long-term follow-up study of artificial dermis composed of outer silicone layerand inner collagen sponge. Br. J. Plast. Surg. 2000, 53, 659-666. [CrossRef] [PubMed]

158. Liu, M.; Zhang, Y.; Wu, C.; Xiong, S.; Zhou, C. Chitosan/halloysite nanotubes bionanocomposites: Structure, mechanical properties and biocompatibility. Int. J. Biol. Macromol. 2012, 51, 566-575. [CrossRef] [PubMed]

159. Kim, S.-K.; Sudha, P.; Aisverya, S.; Rose, M.H.; Venkatesan, J. Bionanocomposites of chitosan for multitissue engineering applications. In Chitin and Chitosan Derivatives: Advances in Drug Discovery and Developments; CRC Press: Boca Raton, FL, USA, 2013; pp. 451-462.

160. Hajiali, H.; Karbasi, S.; Hosseinalipour, M.; Rezaie, H.R. Preparation of a novel biodegradable nanocomposite scaffold based on poly(3-hydroxybutyrate)/bioglass nanoparticles for bone tissue engineering. J. Mater. Sci. Mater. Med. 2010, 21, 2125-2132. [CrossRef] [PubMed]

161. Okamoto, M.; John, B. Synthetic biopolymer nanocomposites for tissue engineering scaffolds. Prog. Polym. Sci. 2013, 38, 1487-1503. [CrossRef]

162. Gábor, K.; Gyula, K. The examination of the role of natural substances in the protection against UV radiation. Hadmérnök 2013, 8, 339-344.

163. Dupont, E.; Gomez, J.; Bilodeau, D. Beyond UV radiation: A skin under challenge. Int. J. Cosmet. Sci. 2013, 35, 224-232. [CrossRef] [PubMed]

164. Gupta, D. UV absorbing properties of some plant derived extracts. Res. J. Chem. Environ. Sci. 2013, 1, 34-36.

165. Saravanan, D. UV protection textile materials. AUTEX Res. J. 2007, 7, 53-62.

166. Smith, G.J.; Miller, I.J.; Clare, J.F.; Diffey, B.L. The effect of UV absorbing sunscreens on the reflectance and the consequent protection of skin. Photochem. Photobiol. 2002, 75, 122-125. [CrossRef]

167. Morgan, A.B.; Antonucci, J.M.; VanLandingham, M.R.; Harris, R.; Kashiwagi, T. Thermal and flammability properties of a silica-PMMA nanocomposite. Polym. Mater. Sci. Eng. Wash. 2000, 83, 57-58.

168. Chee, C.Y.; Yaacob, I.I. Weathering effect on PE coated with thin layer of PU/nanosilica composite. Adv. Mater. Res. 2011. [CrossRef]

169. Mao, Z.; Shi, Q.; Zhang, L.; Cao, H. The formation and UV-blocking property of needle-shaped ZnO nanorod on cotton fabric. Thin Solid Films 2009, 517, 2681-2686. [CrossRef]

170. Song, Q.; Winter, W.T.; Bujanovic, B.M.; Amidon, T.E. Nanofibrillated cellulose (NFC): A high-value co-product that improves the economics of cellulosic ethanol production. Energies 2014, 7, 607-618. [CrossRef]

171. Sarkar, A.K.; Appidi, S. Single bath process for imparting antimicrobial activity and ultraviolet protective property to bamboo viscose fabric. Cellulose 2009, 16, 923-928. [CrossRef]

172. Hoareau, W.; Oliveira, F.B.; Grelier, S.; Siegmund, B.; Frollini, E.; Castellan, A. Fiberboards based on sugarcane bagasse lignin and fibers. Macromol. Mater. Eng. 2006, 291, 829-839. [CrossRef]

173. Cerrutti, B.; de Souza, C.; Castellan, A.; Ruggiero, R.; Frollini, E. Carboxymethyl lignin as stabilizing agent in aqueous ceramic suspensions. Ind. Crops Prod. 2012, 36, 108-115.

174. Binder, J.B.; Raines, R.T. Simple chemical transformation of lignocellulosic biomass into furans for fuels and chemicals. J. Am. Chem. Soc. 2009, 131, 1979-1985. [CrossRef] [PubMed]

175. Nemoto, T.; Konishi, G.-I.; Tojo, Y.; Funaoka, M. Development of lignin as a transparent resin: Evaluation of thermal and optical properties of alkoxylated lignophenols. Polym. J. 2010, 42, 896-900. [CrossRef]

176. Ibn Yaich, A.; Edlund, U.; Albertsson, A.-C. Wood hydrolysate barriers: Performance controlled via selective recovery. Biomacromolecules 2012, 13, 466-473. [CrossRef] [PubMed]

177. Bauer, S.; Arpa-Sancet, M.P.; Finlay, J.A.; Callow, M.E.; Callow, J.A.; Rosenhahn, A. Adhesion of marine fouling organisms on hydrophilic and amphiphilic polysaccharides. Langmuir 2013, 29, 4039-4047. [CrossRef] [PubMed]

178. Findenig, G.; Kargl, R.; Stana-Kleinschek, K.; Ribitsch, V. Interaction and structure in polyelectrolyte/clay multilayers: A QCM-D study. Langmuir 2013, 29, 8544-8553. [CrossRef] [PubMed]

179. Lajimi, R.H.; Ferjani, E.; Roudesli, M.S.; Deratani, A. Effect of LBL surface modification on characteristics and performances of cellulose acetate nanofiltration membranes. Desalination 2011, 266, 78-86. [CrossRef]

180. Jeyachandran, Y.; Mielczarski, E.; Rai, B.; Mielczarski, J. Quantitative and qualitative evaluation of adsorption/desorption of bovine serum albumin on hydrophilic and hydrophobic surfaces. Langmuir 2009, 25, 11614-11620. [CrossRef] [PubMed] 
181. Arora, A.; Padua, G. Review: Nanocomposites in food packaging. J. Food Sci. 2010, 75, R43-R49. [CrossRef] [PubMed]

182. Yee, Y.Y.; Ching, Y.C.; Shaifulazuar, R.; Awanis, H.; Ramesh, S. Preparation and characterization of poly(lactic acid) based composite reinforced with oil palm empty fruit bunch film and nanosilica. Bioresource 2016, 11, 2269-2286. [CrossRef]

183. Burdock, G.A. Safety assessment of hydroxypropyl methylcellulose as a food ingredient. Food Chem. Toxicol. 2007, 45, 2341-2351. [CrossRef] [PubMed]

184. Yu, J.; Cui, G.; Wei, M.; Huang, J. Facile exfoliation of rectorite nanoplatelets in soy protein matrix and reinforced bionanocomposites thereof. J. Appl. Polym. Sci. 2007, 104, 3367-3377. [CrossRef]

185. Panaitescu, D.M.; Frone, A.N.; Chiulan, I. Nanostructured biocomposites from aliphatic polyesters and bacterial cellulose. Ind. Crops Prod. 2016, in press. [CrossRef]

186. Song, Z. Enhancing Moisture Barrier and Grease Resistance of Paper for Green-Based Packaging Materials. Ph.D. Thesis, University of New Brunswick, Saint John, NB, Canada, 2014.

187. Alves, V.D.; Costa, N.; Coelhoso, I.M. Barrier properties of biodegradable composite films based on K-carrageenan/pectin blends and mica flakes. Carbohydr. Polym. 2010, 79, 269-276. [CrossRef]

188. Liu, A.; Berglund, L.A. Clay nanopaper composites of nacre-like structure based on montmorrilonite and cellulose nanofibers-Improvements due to chitosan addition. Carbohydr. Polym. 2012, 87, 53-60. [CrossRef]

189. Andersson, C. New ways to enhance the functionality of paperboard by surface treatment-A review. Packag. Technol. Sci. 2008, 21, 339-373. [CrossRef]

190. Bordenave, N.; Grelier, S.; Coma, V. Hydrophobization and antimicrobial activity of chitosan and paper-based packaging material. Biomacromolecules 2009, 11, 88-96. [CrossRef] [PubMed]

191. Lu, P.; Xiao, H.; Zhang, W.; Gong, G. Reactive coating of soybean oil-based polymer on nanofibrillated cellulose film for water vapor barrier packaging. Carbohydr. Polym. 2014, 111, 524-529. [CrossRef] [PubMed]

192. Çolak, S.; Küsefoğlu, S.H. Synthesis and interfacial properties of aminosilane derivative of acrylated epoxidized soybean oil. J. Appl. Polym. Sci. 2007, 104, 2244-2253. [CrossRef]

193. Rhim, J.-W.; Ng, P.K. Natural biopolymer-based nanocomposite films for packaging applications. Crit. Rev. Food Sci. Nutr. 2007, 47, 411-433. [CrossRef] [PubMed]

194. Casariego, A.; Souza, B.; Cerqueira, M.; Teixeira, J.; Cruz, L.; Díaz, R.; Vicente, A. Chitosan/clay films' properties as affected by biopolymer and clay micro/nanoparticles' concentrations. Food Hydrocoll. 2009, 23, 1895-1902. [CrossRef]

195. Wang, L.; Wang, A. Adsorption characteristics of Congo Red onto the chitosan/montmorillonite nanocomposite. J. Hazard. Mater. 2007, 147, 979-985. [CrossRef] [PubMed]

196. Dufresne, A. Polysaccharide nano crystal reinforced nanocomposites. Can. J. Chem. 2008, 86, 484-494. [CrossRef]

197. Dubief, D.; Samain, E.; Dufresne, A. Polysaccharide microcrystals reinforced amorphous poly( $\beta$-hydroxyoctanoate) nanocomposite materials. Macromolecules 1999, 32, 5765-5771. [CrossRef]

198. Wong, K.K.H.; Zinke-Allmang, M.; Hutter, J.L.; Hrapovic, S.; Luong, J.H.; Wan, W. The effect of carbon nanotube aspect ratio and loading on the elastic modulus of electrospun poly(vinyl alcohol)-carbon nanotube hybrid fibers. Carbon 2009, 47, 2571-2578. [CrossRef]

199. Nakagaito, A.N.; Yano, H. The effect of fiber content on the mechanical and thermal expansion properties of biocomposites based on microfibrillated cellulose. Cellulose 2008, 15, 555-559. [CrossRef]

200. Nakagaito, A.; Yano, H. Novel high-strength biocomposites based on microfibrillated cellulose having nano-order-unit web-like network structure. Appl. Phys. A 2005, 80, 155-159. [CrossRef]

201. Okahisa, Y.; Yoshida, A.; Miyaguchi, S.; Yano, H. Optically transparent wood-cellulose nanocomposite as a base substrate for flexible organic light-emitting diode displays. Compos. Sci. Technol. 2009, 69, 1958-1961. [CrossRef]

202. Ching, Y.C.; Rahman, A.; Ching, K.Y.; Sukiman, N.L.; Cheng, H.C. Preparation and characterization of polyvinyl alcohol-based composite reinforced with nanocellulose and nanosilica. BioResources 2015, 10, 3364-3377. [CrossRef]

203. De Mesquita, J.P.; Donnici, C.L.; Teixeira, I.F.; Pereira, F.V. Bio-based nanocomposites obtained through covalent linkage between chitosan and cellulose nanocrystals. Carbohydr. Polym. 2012, 90, 210-217. [CrossRef] [PubMed] 
204. Galus, S.; Kadzińska, J. Food applications of emulsion-based edible films and coatings. Trends Food Sci. Technol. 2015, 45, 273-283. [CrossRef]

205. Montes, S.; Carrasco, P.M.; Ruiz, V.; Cabañero, G.; Grande, H.J.; Labidi, J.; Odriozola, I. Synergistic reinforcement of poly(vinyl alcohol) nanocomposites with cellulose nanocrystal-stabilized graphene. Compos. Sci. Technol. 2015, 117, 26-31. [CrossRef]

206. Lin, S.; Chen, L.; Huang, L.; Cao, S.; Luo, X.; Liu, K. Novel antimicrobial chitosan-cellulose composite films bioconjugated with silver nanoparticles. Ind. Crops Prod. 2015, 70, 395-403. [CrossRef]

207. Lizundia, E.; Urruchi, A.; Vilas, J.; León, L. Increased functional properties and thermal stability of flexible cellulose nanocrystal/ZnO films. Carbohydr. Polym. 2016, 136, 250-258. [CrossRef] [PubMed]

208. Zarina, S.; Ahmad, I. Biodegradable composite films based on $\mathrm{k}$-carrageenan reinforced by cellulose nanocrystal from kenaf fibers. BioResources 2014, 10, 256-271. [CrossRef]

209. Li, H.-Z.; Chen, S.-C.; Wang, Y.-Z. Preparation and characterization of nanocomposites of polyvinyl alcohol/cellulose nanowhiskers/chitosan. Compos. Sci. Technol. 2015, 115, 60-65. [CrossRef]

210. Atef, M.; Rezaei, M.; Behrooz, R. Characterization of physical, mechanical, and antibacterial properties of agar-cellulose bionanocomposite films incorporated with savory essential oil. Food Hydrocoll. 2015, 45, 150-157. [CrossRef]

211. El Miri, N.; Abdelouahdi, K.; Barakat, A.; Zahouily, M.; Fihri, A.; Solhy, A.; el Achaby, M. Bio-nanocomposite films reinforced with cellulose nanocrystals: Rheology of film-forming solutions, transparency, water vapor barrier and tensile properties of films. Carbohydr. Polym. 2015, 129, 156-167. [CrossRef] [PubMed]

212. Jafarzadeh, S.; Alias, A.K.; Ariffin, F.; Mahmud, S.; Najafi, A. Preparation and characterization of bionanocomposite films reinforced with nano kaolin. J. Food Sci. Technol. 2015, 53, 1111-1119. [CrossRef] [PubMed]

213. Chen, G.; Zhang, B.; Zhao, J. Dispersion process and effect of oleic acid on properties of cellulose sulfate-oleic acid composite film. Materials 2015, 8, 2346-2360. [CrossRef]

214. Rubentheren, V.; Ward, T.A.; Chee, C.Y.; Tang, C.K. Processing and analysis of chitosan nanocomposites reinforced with chitin whiskers and tannic acid as a crosslinker. Carbohydr. Polym. 2015, 115, 379-387. [CrossRef] [PubMed]

215. Rubentheren, V.; Ward, T.A.; Chee, C.Y.; Nair, P. Physical and chemical reinforcement of chitosan film using nanocrystalline cellulose and tannic acid. Cellulose 2015, 22, 2529-2541. [CrossRef] 